This item was submitted to Loughborough's Research Repository by the author.

Items in Figshare are protected by copyright, with all rights reserved, unless otherwise indicated.

\title{
Constructing rainfall thresholds for debris flow initiation based on critical discharge and S-hydrograph
}

\section{PLEASE CITE THE PUBLISHED VERSION}

https://doi.org/10.1016/j.enggeo.2020.105962

\section{PUBLISHER}

Elsevier

\section{VERSION}

AM (Accepted Manuscript)

\section{PUBLISHER STATEMENT}

This paper was accepted for publication in the journal Engineering Geology and the definitive published version is available at https://doi.org/10.1016/j.enggeo.2020.105962

\section{LICENCE}

CC BY-NC-ND 4.0

\section{REPOSITORY RECORD}

Lin, Yajun, Xingmin Meng, Peng Guo, Tom Dijkstra, Yan Zhao, Guan Chen, and Dongxia Yue. 2020. "Constructing Rainfall Thresholds for Debris Flow Initiation Based on Critical Discharge and S-hydrograph". Loughborough University. https://hdl.handle.net/2134/13625987.v1. 


\title{
Constructing rainfall thresholds for debris flow initiation based on critical
}

discharge and S-hydrograph

NB - this is the author's final copy and differences with the published manuscript may exist. Yajun $\mathrm{Li}^{1}$, Xingmin Meng ${ }^{1 *}$, Peng Guo ${ }^{1}$, Tom Dijkstra ${ }^{2}$, Yan Zhao ${ }^{1}$, Guan Chen ${ }^{1}$, Dongxia Yue ${ }^{2}$

\author{
${ }^{1}$ School of Earth Sciences, Lanzhou University, Lanzhou, 73000, P.R. China \\ ${ }^{2}$ School of Architecture, Building and Civil Engineering, Loughborough University, \\ ${ }^{2}$ College of Earth and Environmental Sciences, Lanzhou University, Lanzhou, 73000, \\ P.R. China \\ *Corresponding author: Xingmin Meng (xmmeng@1zu.edu.cn) \\ Conflict of interest: None.

\section{Abstract}

Debris flows caused by channel bed erosion present major hazards affecting life, livelihoods, and the built environment in mountainous regions. An efficient way to decrease hazard impact is through reliable hazard forecasts and appropriate earlywarning strategies. Rainfall thresholds are fundamental in achieving reliable hazard forecasts. However, a lack of rainfall records often impedes the empirical establishment of such thresholds. This paper constructs rainfall intensity-duration thresholds based on process-based critical runoff discharge for the initiation of debris flows and a mathematical approximation among peak discharge, rainfall intensity and duration. Simulations of conditions that triggered debris flow and non-debris flow events allowed determination of the lower and upper limits of critical discharge for debris flow initiation. In turn, these critical discharge limits are compared with four estimates derived from process-based approaches to test which approach best delimit the critical conditions. Hydrological simulations derive S-hydrographs for recorded rainfall events. Further analysis of the S-hydrographs results in a mathematical approximation of peak discharge as a function of rainfall intensity and duration and the establishment of the minimum rainfall required to produce a particular peak discharge. The minimum rainfall threshold to trigger an event can be calculated by setting the process-based 
critical discharge as the peak discharge. In turn, this enables the establishment of a conventional rainfall I-D threshold for debris flow initiation. This process-based approach enables the construction of valley-specific I-D thresholds in data-poor areas and provides a promising pathway to improve the reliability of debris flow hazard forecasts and early warnings.

Key words: debris flow initiation; rainfall thresholds; Intensity-duration; channel bed erosion; hydrological model

\section{Introduction}

Debris flows are frequently occurring mass movement processes in mountainous regions that can cause substantial loss of life and damage to the built environment, affecting housing, livelihoods and infrastructure (Jakob and Hungr, 2005; Chen et al., 2016; Thiene et al., 2017). The tectonically active eastern margin of the Tibetan Plateau (TP) is particularly affected by large-scale uplift and denudation phases that result in widespread mass movement activity (Fan et al., 2018; Li et al., 2018; Parker et al., 2011; Tang et al., 2009; 2012). As a consequence, many valleys hold substantial quantities of channel-bed sediments. Following intense rainstorms, these materials can be initiated by runoff and transformed into large-scale catastrophic debris flows (Chen et al., 2019; Dijkstra et al., 2012; Fan et al., 2018; Gregoretti et al., 2018; Hu et al., 2014; Reid et al., 2016; Simoni et al., 2020; Tang et al., 2011; 2012; Yu et al., 2014). The need to reduce the potential impact of such debris flows has been recognized throughout this region (Cui et al., 2011; Guo et al., 2016; Xiong et al., 2016).

One of the approaches to achieve improved debris flow forecasts is through the establishment of a rainfall threshold for a given region (Aleotti, 2004; Baum and Godt 2010; Papa et al., 2013; Chen et al., 2016; Staley et al., 2017). This rainfall threshold is usually defined as a relation between rainfall intensity and duration (I-D) ( Brunetti et al., 2010; Caine, 1980; Guzzetti et al., 2008; Staley et al., 2013; Wei et al., 2017; Winter et al., 2010) with the idea that the combination of these two factors (rainfall intensity and rainfall duration) determines the threshold. The I-D relation has been commonly 
obtained using statistical methods to analyze recorded rainfall events with debris flow occurrence (Guzzetti et al., 2008; Winter et al., 2010; Zhuang et al., 2015). However, a lack of observation data in high mountainous areas has made it difficult to accurately define rainfall I-D thresholds for most debris-flow basins (McGuire et al., 2017; Pan et al., 2018; Tang et al., 2019). Consequently, it is fundamental to develop methods to enable the establishment of locality-specific I-D thresholds for regions that lack recorded debris flow observations (Pan et al., 2018; Papa et al., 2013; Tang et al., 2019).

The mechanisms of runoff-generated debris flows include gradual sediment entrainment (Cannon et al., 2001; Mcguire et al., 2017; Meyer and Wells, 1997), the firehose effect (Berti et al., 2020; Tognacca et al., 2000; Lanzoni et al., 2017), and mass failure of channel sediment (Kean et al., 2013; McGuire et al., 2017, Tang et al., 2019). A critical discharge approach has been used to define the initiation conditions of debris flows caused by hydrodynamic forces (Gregoretti and Dalla Fontana, 2008; Gong et al., 2020; Pastorello et al., 2020), and the concept of critical discharge is extended to bed failure using a solid-liquid critical discharge process proposed by Tang et al. (2019). Takahashi (1978) proposed an equation to calculate the critical water depth that causes channel bed failure, and this critical water depth can be transformed into critical discharges by considering channel characteristics (channel width, channel slope and roughness).

This study conducts a mathematical exercise to 1) test whether critical discharges exist for debris flow initiation by comparing the simulated peak discharges of observed debris flow and non-debris flow rainfall events and 2) to construct I-D thresholds based on critical discharges and the approximated relation among rainfall intensity, duration, and peak discharges. Following the methodology proposed by Gregoretti and Dalla Fontana (2008), we use a spatially distributed hydrological model (Du et al., 2009; Muzik, 1996) to estimate the peak discharges for debris flow and non-debris flow events in the initiation area of a valley. This model uses the Soil Conservation Services and Curve Number (SCS-CN) method to estimate excess rainfall (e.g., Gregoretti and Dalla Fontana, 2008; Pastorello et al., 2020 ), although it is worth noting that Gregoretti et al (2016) showed that this method is not always suitable for computing excess rainfall in 
a steep mountain environment.

In our model, simulated peak discharges for recorded debris flow and non-debris flow events enabled 1) the identification of the lower limit of critical discharge for debris flow events based on the lowest peak discharges for recorded debris flow events and 2) the identification of the upper limit of critical discharge based on the highest peak discharge for recorded non-debris flow events (see for example Cannon et al., 2008; Staley et al., 2013). These upper and lower limits are then compared with empirical values derived from four different physically-based approaches (Gregoretti and Dalla Fontana, 2008; Lamb et al., 2008; Takahashi, 1978; Tognacca et al., 2000) to test which approach best approaches the lower/upper limit of the critical condition. A mathematical relation among peak discharge, rainfall intensity and duration is derived by analyzing the S-hydrographs that are produced by hydrological simulations of recorded rainfall events. An analytical method of producing I-D thresholds is developed based on this approximated relation among rainfall intensity, duration, and peak discharges and the process-based critical discharges. This approach is different from that used by Berti et al (2020) because we focus on analyzing the characteristics of the S-hydrographs to obtain the approximated I-D threshold. This method does not require observations of debris flows and only needs inputs such as topography, land-use and near-surface material characteristics. Therefore, it provides a promising approach for application in data-poor basins that are prone to debris flows generated by runoff processes.

\section{Materials and methods}

\subsection{Study area}

The Bailong River is positioned in the intersection between the Eastern Tibetan Plateau and the Western Qin Mountain in China (Figure 1), featuring high-relief and steeply-incised valleys (Chen et al., 2018; Zhang et al., 2012; Zhang et al., 2016; Zhang et al., 2018; Zhao et al., 2020). The climate is controlled by the Asian monsoon system, which is characterized by warm and humid summers and dry and cold winters (Railsback et al., 2014). Populations in this area are at great risks of debris flow hazards 
(Dijkstra et al., 2014; Wang et al., 2017; Xiong et al., 2016). The devastating debris

flows occurring on August 8, 2010, in Zhouqu, which killed 1765 people and destroyed about 5500 houses, provide an extreme example of how debris flows can have very serious consequences in this region (Tang et al., 2011; Wang, 2013; Xiong et al. 2016).

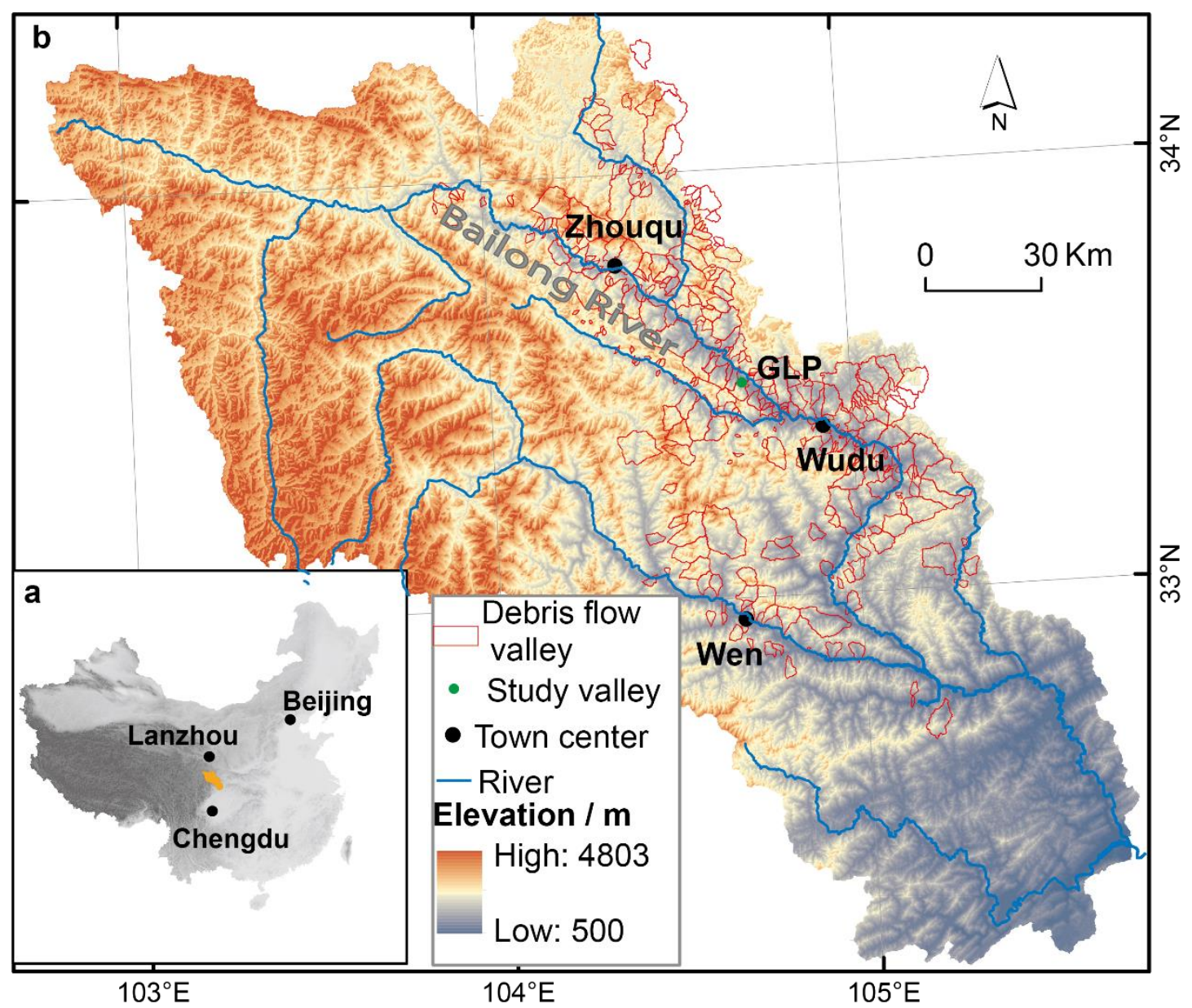

Figure 1 Location of the Bailong River and the GLP valley. a. Relative location of the Bailong River (the area shaded orange) in China. b. The drainage area of the Bailong River and the location of the GLP valley. The background image is a 30-m resolution ASTER DEM. Zhouqu, Wudu and Wen are the three important county centers along the Bailong River.

The Goulinping (GLP) basin (N 3332'24", E 104 39'13"), with a watershed area of $20 \mathrm{~km}^{2}$ and a relief of $1897 \mathrm{~m}$, is positioned in the middle section of the Bailong River (Figures $2 \& 3$ ). The channel bed is filled with very thick gravels and cobbles, up 
to a depth of about $50-60 \mathrm{~m}$ beneath the ground (Li et al., 2018). Bedrock in the upstream section comprises mainly Carboniferous limestones. Downstream, these

137 limestones are bounded by a reverse fault, and the lithology is dominated by phyllites. The limestone hillslopes are covered by brush and coniferous forest, while the phyllite hillslopes are covered by sparse grasses. Bedrocks at relatively gentle hillslopes are covered by regolith that is the source of gravel-dominated accumulations in the valleybase. Debris flows in this valley occur on average six times per year, and the materials are mainly sourced from the channel fills which are composed of legacies of paleodebris flow sediments since the Last Glacial period (Li et al., 2018), and rockfalls developing in the faulting area.

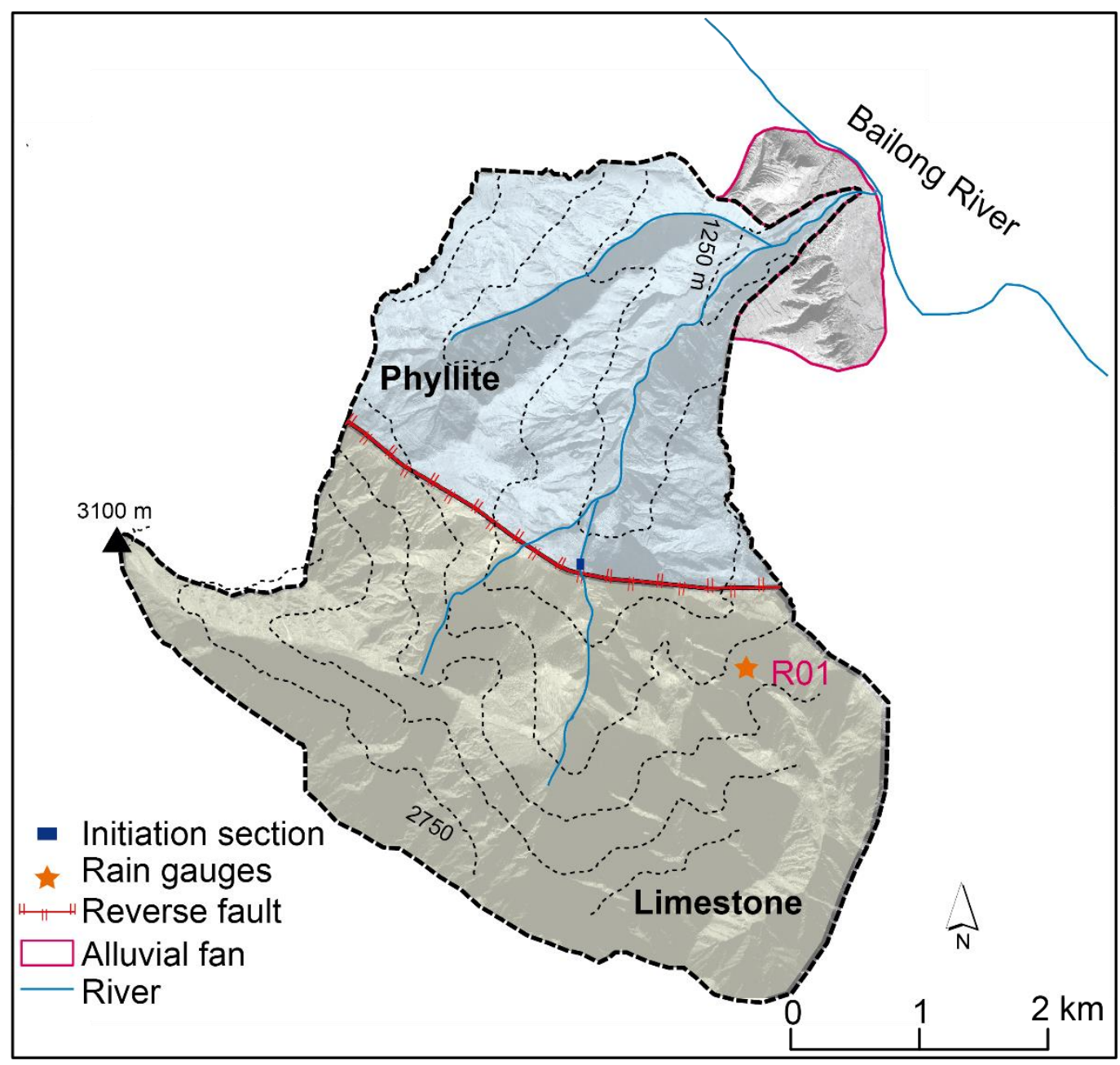

Figure 2 Background settings of the Goulinping basin 


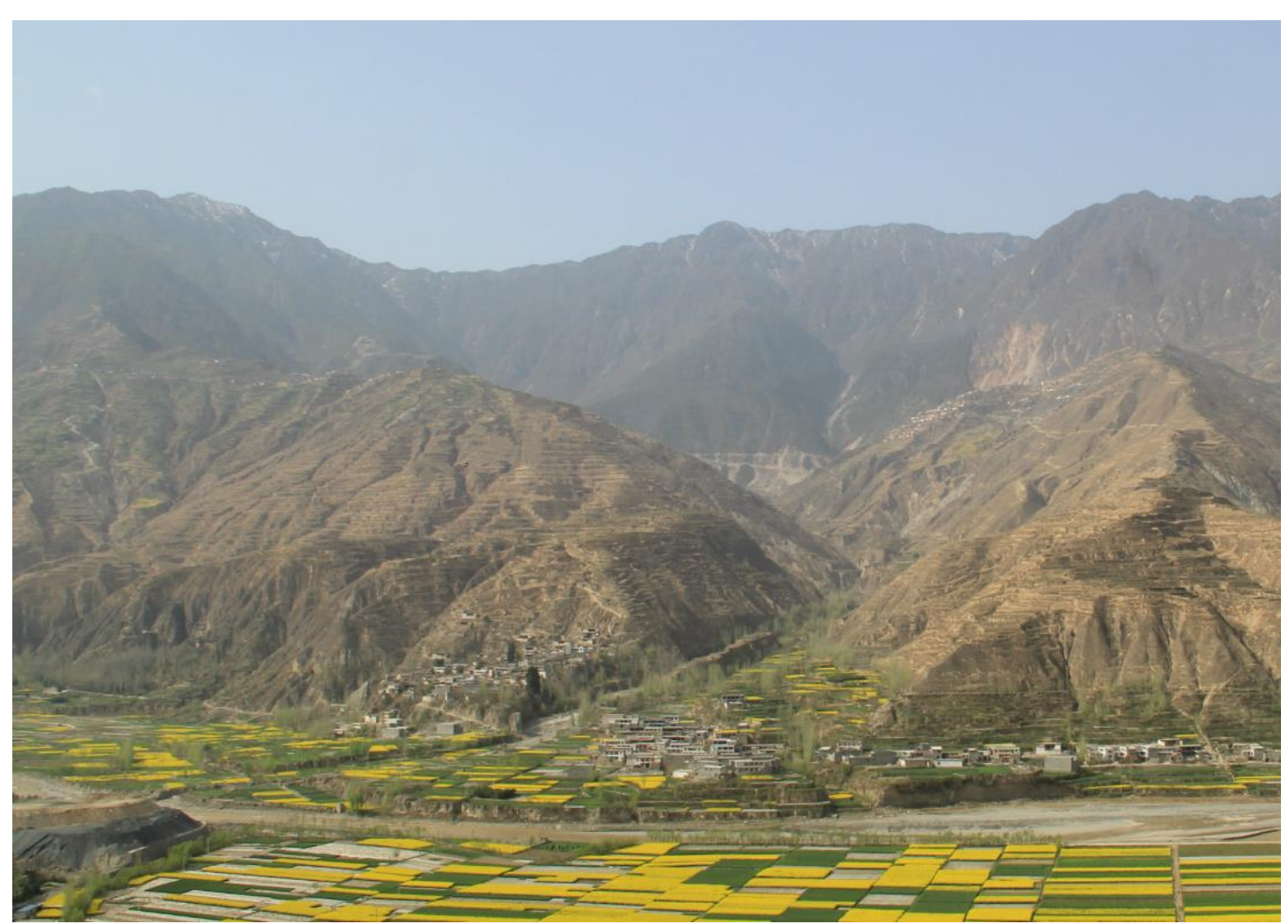

Figure 3 Photograph of the GLP valley

\subsection{Records of rainfall and debris flow events and characteristics of initiation area}

One rain gauge (denoted as R01) was installed in the upper part of the basin in December 2012 (Figure 2). This rain gauge provides rainfall data with a resolution of $0.2 \mathrm{~mm}$ and samples rainfall depth at intervals of 1 or 5 minutes. In this study, the records of the period between 2013-02-01 and 2015-04-18 are used for analyses. To determine debris flow events, monthly visits to the valley were made to ask local villagers to recall whether or not debris flow events occurred during the time interval to the most recent visit. We described debris flows as 'muddy floods with little turbulence and gravels occasionally floating on the top of the fluid', and a debris flow event was determined if villagers have seen such a process. Rainfall records were also checked to ascertain periods in which debris flow events have occurred. Through this method, we were able to identify the dates of debris flow events and to select the associated rainfall records. However, we were unable to determine the exact timing of each debris flow event.

The triggering area of debris flows is determined through field investigation. Following debris flow events, we visited the upper part of the valley, and the uppermost 
section with obvious erosion marks and transport pathways was regarded as the initiation area. The characteristics of the sediments and channel morphology (including grain size distribution, channel bed slope and width) were measured in this initiation area.

The grain size distribution was determined using the method of sieving. Four bags of samples (2-5 kg in weight for each bag) were taken from the channel bed in the initiation section. These samples were dried in the lab and sieved through a series of meshes $(60,40,20,10,5,2,1,0.5,0.25,0.075,0.05,0.025 \mathrm{~mm})$, and the weight of the materials remaining on different meshes was measured to produce a grain size curve (Figure 4). The channel bed slope and channel width were measured using a laser ranger finder.

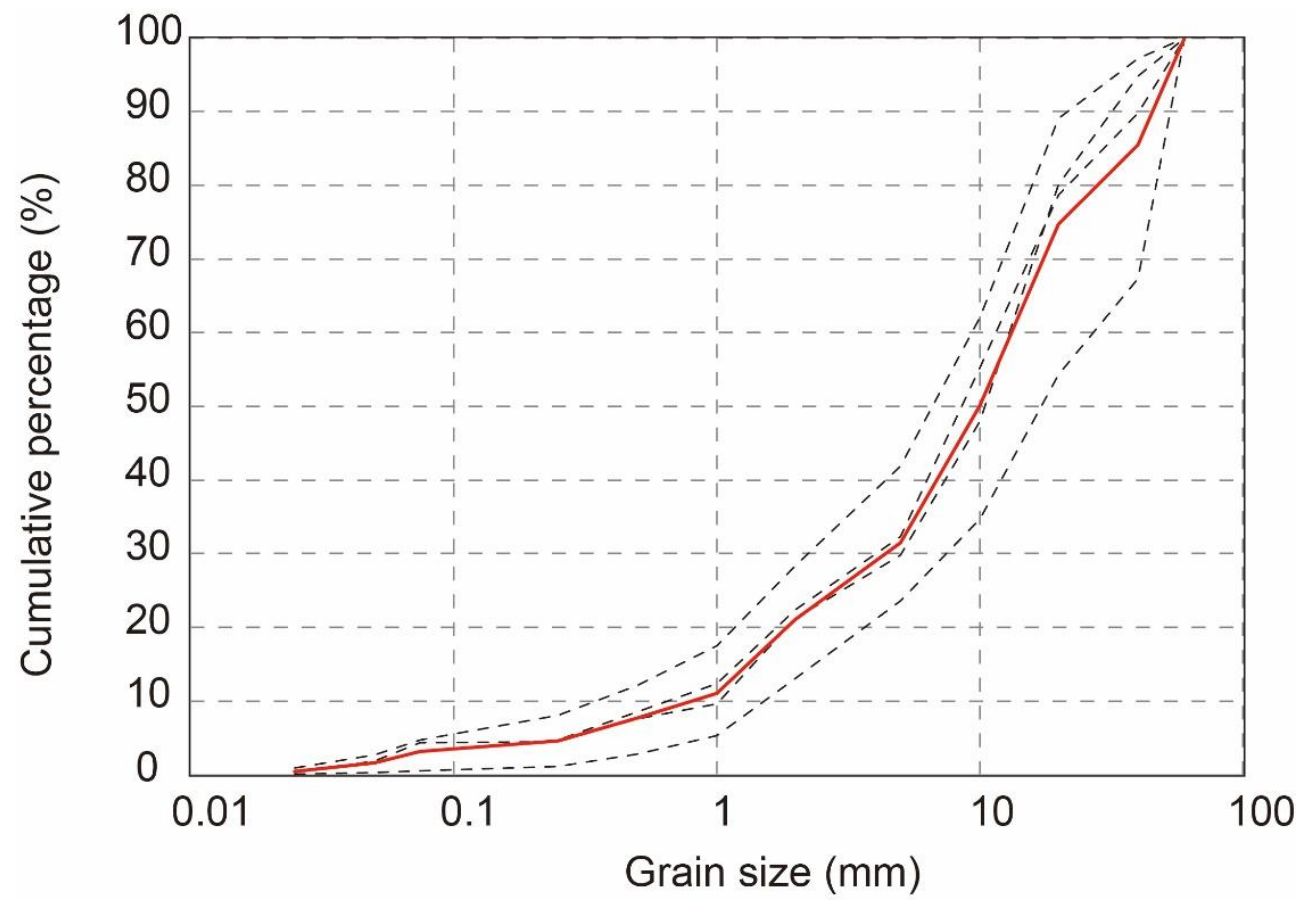

Figure 4 Grain size distribution of sediments in the triggering area of the valley. Dashed lines are measured distribution of four samples from the triggering area, and the red line is the average value.

\subsection{Determination of process-based critical discharges}

We calculated the process-based critical discharges using the four approaches proposed by Takahashi (1978) (Eq. 1), Tognacca et al. (2000) (Eq.2), Gregoretti and 
Dalla Fontana (2008) (Eq. 3) and Lamb et al. (2008) (Eq. 4)

$$
h=\left[\frac{C_{*}\left(\rho_{s}-\rho_{w}\right) \tan \varphi}{\rho_{w} \tan \theta}-\frac{C_{*}\left(\rho_{s}-\rho_{w}\right)}{\rho_{w}}-1\right] d
$$

$$
q^{*}=\frac{q}{\sqrt{\frac{\rho_{-}-\rho_{W}}{\rho_{W}} g d^{3}}}=\frac{1.0}{\tan \theta^{1.17}}
$$

$$
q^{*}=\frac{q}{\sqrt{\frac{\rho_{S}-\rho_{W}}{\rho_{W}} g d^{3}}}=\frac{0.195}{\tan \theta^{1.27}}
$$

$$
\tau_{*}=\frac{h \sin \theta}{\left(\left(\rho_{s}-\rho_{w}\right) / \rho_{w} d\right.}=\exp \left[P_{4} X^{4}+P_{3} X^{3}+P_{2} X^{2}+P_{1} X+P_{0}\right]
$$

190

Where $h$ is the water depth; $q *$ is the critical dimensionless discharge per unit width; $\tau_{*}$ is the critical Shields' stress. $C_{*}$ is the volume concentration of solid materials, $\rho_{S}$ and $\rho_{w}$ are the density of solid materials and water $\left(\mathrm{kg} / \mathrm{m}^{3}\right)$, respectively; $\varphi$ is the internal friction angle; $\theta$ is the channel bed slope (percentage); $d$ is the average grain diameter $(\mathrm{m}) ; q$ is the critical discharge per unit width $\left(\mathrm{m}^{2} / \mathrm{s}\right) ; \quad X=$

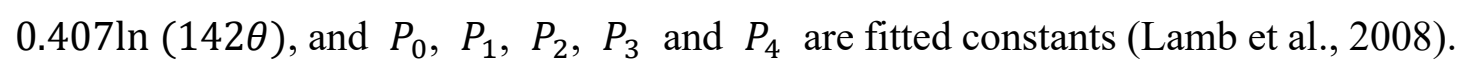
In calculation, the values of $\rho_{S}$ and $C_{*}$ are taken from local geotechnical investigation reports (Table 1). Manning's equation is used to transform the critical water depths that are produced by the approaches of Takahashi (1978) and Lamb et al. (2008) to critical discharge: $Q=\frac{(W \times h) \times \theta^{1 / 2} \times R^{2 / 3}}{n}$, where $R$ is hydraulic radius (approximated as water depth ( $h$ ) for wide channels), and $W$ is channel width. 
Table 1 Parameters and results for critical discharge calculation using different approaches. $W$ is the channel width at the initiation section. $h$ is the critical water

\begin{tabular}{|c|c|c|c|c|c|c|c|}
\hline $\begin{array}{c}d \\
(\mathrm{~mm})\end{array}$ & $\begin{array}{c}\theta \\
\text { (percent) }\end{array}$ & $\begin{array}{c}\varphi \\
\text { (percent) }\end{array}$ & $\begin{array}{c}C_{*} \\
1\end{array}$ & $\begin{array}{c}\rho_{s} \\
\mathrm{~g} / \mathrm{cm}^{3}\end{array}$ & $\begin{array}{c}\rho_{w} \\
\mathrm{~g} / \mathrm{cm}^{3}\end{array}$ & $\begin{array}{l}W \\
\mathrm{~m}\end{array}$ & $\begin{array}{l}n \\
1\end{array}$ \\
\hline $17 \pm 1$ & $0.3 \pm 0.02$ & $0.8 \pm 0.03$ & $0.83 \pm 0.1$ & $2.65 \pm 0.1$ & $1 \pm 0.1$ & $10 \pm 0.5$ & $0.04 \pm 0.01$ \\
\hline $\begin{array}{c}h \\
(\mathrm{~mm})\end{array}$ & $\begin{array}{c}q_{\text {greg }}^{*} \\
1\end{array}$ & $\begin{array}{c}q_{\text {tog }}^{*} \\
1\end{array}$ & $\begin{array}{c}\tau_{*} \\
1\end{array}$ & $\begin{array}{c}Q_{\text {tak }} \\
\left(\mathrm{m}^{3} / \mathrm{s}\right)\end{array}$ & $\begin{array}{l}Q_{\text {greg }} \\
\left(\mathrm{m}^{3} / \mathrm{s}\right)\end{array}$ & $\begin{array}{c}Q_{t o g} \\
\left(\mathrm{~m}^{3} / \mathrm{s}\right)\end{array}$ & $\begin{array}{l}Q_{\text {lamb }} \\
\left(\mathrm{m}^{3} / \mathrm{s}\right)\end{array}$ \\
\hline $35 \pm 7$ & $0.88 \pm 0.05$ & $4 \pm 0.2$ & $0.18 \pm 0.01$ & $0.51 \pm 0.2$ & $0.08 \pm 0.01$ & $0.36 \pm 0.06$ & $0.15 \pm 0.05$ \\
\hline
\end{tabular}

\subsection{Rainfall-runoff model}

For the simulation of rainfall-runoff relationships, the Spatial Distributed Travel grid cell (Du et al., 2009; Melesse and Graham 2004; Muzik, 1996; Zuazo et al., 2014). This study constructs an SDTT model using Model Builder in ArcGIS to simulate the flood hydrographs of observed rainfall storms in the GLP valley. An ALOS (Advanced Land Observing Satellite) digital elevation model (DEM) with a resolution of $12.5 \mathrm{~m}$ is used for hydrological simulation. The hydrological model uses a Soil Conservation Service runoff curve (SCS-CN) to calculate excess rainfall for different land units. It then uses the method proposed by Muzik (1996) to estimate the velocities of overland flow and channel flow to obtain the concentration time of the excess rainfall from each cell to the valley outlet. The unit hydrograph and the actual flood hydrograph are then obtained. A detailed description of the model is below:

\section{(1) Excess rainfall}

The first part is to calculate the excess rainfall for different types of land units. The 
SCS-CN model is used to estimate runoff. The SCS-CN model is a simple and widely used empirical model that considers the heterogeneity of different hydrological units within a watershed. This model assumes that, for each hydrologic unit, the ratio of actual soil retention after runoff to the potential maximum retention is equal to the ratio of direct runoff to available rainfall (Xiao et al., 2011). The basic formula is:

$$
\frac{F}{S}=\frac{Q}{P-I_{a}}
$$

Where $F$ is cumulative infiltration, $S$ is potential maximum retention or infiltration (mm), $Q$ is runoff (mm), $P$ is storm rainfall $(\mathrm{mm}), I_{a}$ is initial abstraction. The value of $I_{a}$ is often set equal to $0.2 \mathrm{~S}$, but is currently under much debate with proposals forwarded to significantly decrease this value for more realistic results (see e.g. Hawkins et al., 2019). However, taking into account the specific local geomorphological setting of the GLP we feel that a value of $0.2 \mathrm{~S}$ is adequate for this case, but that this value would need careful scrutiny on a case by case basis.

Therefore, the model can be expressed as follows:

$$
Q= \begin{cases}\frac{(P-0.2 S)^{2}}{P+0.8 S} & P \geq 0.2 S \\ 0 & P \leq 0.2 S\end{cases}
$$

$S$ is expressed in the form of a dimensionless runoff curve number (CN) (Eq. 7) which can be determined by referring to the SCS manual (USDA, 1985) according to the soil antecedent moisture condition (AMC), infiltration rate, and types of land uses.

$$
S=\frac{25400}{C N}-254
$$

In this study, we use a Google-earth image ( $1 \mathrm{~m}$ spatial resolution) to produce the land use map of the valley (Figure 5a). The hydrological soil groups (HSG) are determined by considering the characteristics of soil textures, which were empirically estimated during field investigation (Table 2): the channel beds and bare slope surfaces are covered by coarse gravelly sediments and are assigned an A-type HSG; the land use units of residential areas, row crops, and herbaceous areas mainly develop where fine loessic materials cover the slopes and are assigned a D-type HSG; the land use of bushes and forests develops in soils which have rock fragments and clayey loams and are assigned a C-type HSG. We only adopt the $\mathrm{CN}$ values for averaged soil moisture 
conditions because the relatively steep hillslopes in most parts of the watershed (Figure $5 \mathrm{~b})$ largely impede the presence of saturated conditions of soils. The total amount of rainfall for each event is used to calculate the excess rainfall (see Figure 5c for an example).

Table $2 \mathrm{CN}$ numbers for different land uses. HSG refers to hydrological soil groups and HC refers to hydrological conditions. $\mathrm{n}$ is Manning's coefficient, referred from Chow (1959)

\begin{tabular}{lllll}
\hline Land use & HSG & HC & CN & n \\
\hline Woods & C & Poor & 82 & 0.16 \\
Row Crops & D & Poor & 88 & 0.035 \\
Bush & C & Poor & 83 & 0.1 \\
Bareland & A & -- & 77 & 0.025 \\
Herbaceous & D & Fair & 89 & 0.035 \\
Residential area & D & Poor & 92 & 0.015 \\
Channel floor & A & Poor & 45 & 0.07 \\
\hline
\end{tabular}

(2) Runoff routing (overland and channel flow)

The hydrological model routes the excess rainfalls from each cell to an outlet section, and the runoff discharge at the outlet at a given time is determined by summing up all the excess rainfalls that flows to the outlet at this time. The hydrological model compute flow paths following the steepest direction from each cell to its outlet section. The flow paths are divided into channel and slope sections to account for the distinct propagation speeds that characterize different portions of the watershed. We divide slopes and channels based on a minimum number of contributing cells upstream: any cell with a number of upstream contributing cells equal to or greater than the threshold value is defined as a channel cell; others are hillslope cells.

The overland hillslope velocity $\left(V_{o}\right)$ is calculated by combining a steady-state kinematic wave approximation with Manning's equation (Eq. 8, Melesse and Graham, 
2004; Muzik, 1996), while the channel velocity $\left(V_{c}\right)$ is given by combining the approximated Manning's equation and the continuity equation (Eq. 9, Du et al., 2009)

$$
V_{o}=\frac{i_{c}{ }^{0.4} \theta^{0.3} l^{0.4}}{n^{0.6}}
$$

$$
V_{c}=\frac{\theta^{3 / 8} Q^{1 / 4}}{n^{3 / 4}}
$$

Where $V_{o}$ and $V_{c}$ are the overland flow velocity and channel velocity respectively, $i_{c}$ is the excess rainfall intensity (calculated as the excess rainfall for the cell divided by rainfall duration, with units of $\mathrm{m} / \mathrm{s}), l$ is surface flow length $(\mathrm{m})$ for each cell. 1 equals to grid size if the cell has horizontal or vertical flow directions; otherwise it equals to the grid size multiplied by $\sqrt{2}$., $n$ is Manning's coefficient, $\theta$ is slope gradient (meter/meter), $Q$ is the discharge $\left(\mathrm{m}^{3} / \mathrm{s}\right)$ through the cell and is determined by summing up the upstream flow contributions and the contribution from excess precipitation for that cell. In this method, the Manning's $n$ is determined by referring to Chow's (1959) table. An example of calculated velocity is presented in Figure 5d.

The travel time $(\mathrm{t})$ of excess rainfall flowing out of a cell is computed as

$$
t=l / V
$$

Where $V$ is the flow velocity for each cell. If the cell is a hillslope portion, $V=V_{o}$; otherwise, $V=V_{c}$.

The time of excess rainfall flowing from a cell to the outlet is computed by summing up the travel times along the respective flow paths. An unit-time hydrograph can be produced by summing up the excess rainfall from all the cells that arrive at the outlet within the unit-time interval, and a hydrograph is produced by convoluting discretized rainfall duration (rainfall duration/time interval) with the unit-time hydrograph. We have calculated peak discharge using different time intervals (1 min, 2 $\mathrm{min}, 5 \mathrm{~min}, 10 \mathrm{~min}, 15 \mathrm{~min}$ and $75 \mathrm{~min}$ ) for the rainfall event occurring on 2012-05-11, and all these intervals produce the same value of peak discharge $\left(15 \mathrm{~m}^{3} / \mathrm{s}\right)$, indicating that the time interval is not a sensitive parameter. In this study, we set $10 \mathrm{~min}$ as the interval for unit hydrographs because this interval provides sufficient temporal detail for runoff processes corresponding to short and intense rainfalls. 

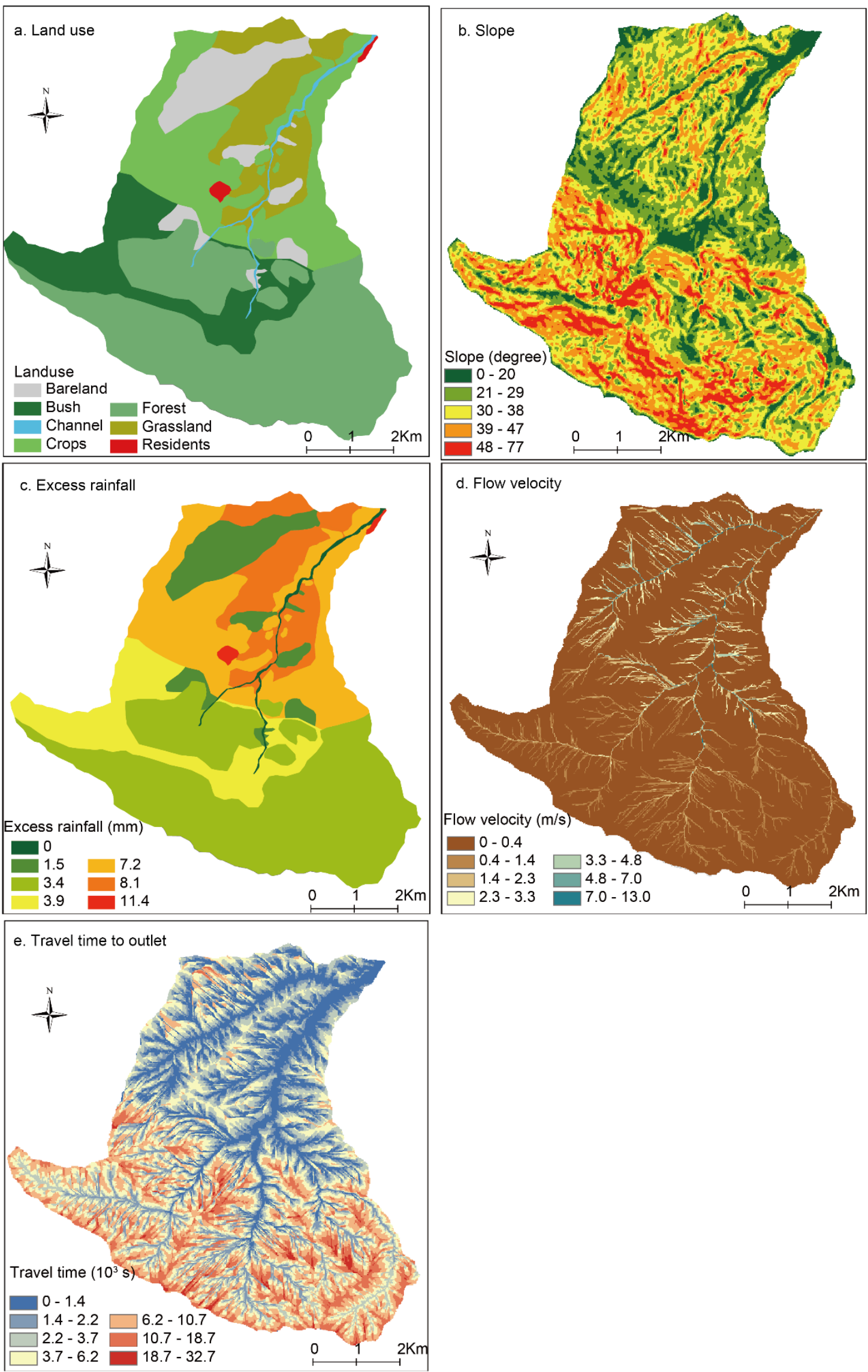

Figure 5 Input and output for the hydrological model. a. map of land use for the 
GLP valley; b. map of slope; c. map of excess rainfall corresponding to the rainfall event on 2012-05-11; d. map of flow velocity corresponding to the same rainfall event; e. map of the travel time of each cell flowing to the outlet of the valley.

\section{Results}

\subsection{Observed rainfall and debris flow events}

The daily rainfall, recorded by rain gauge R01 between 2013-02-01 and 2015-0418, is presented in Figure 6. The annual rainfall for 2013 and 2014 is $651.7 \mathrm{~mm}$ and $611 \mathrm{~mm}$, respectively. 22 rainfall events have totals larger than $17 \mathrm{~mm}$. Analyzing these rainfall events reveals two types of rainfall: 1) rainfall with low-intensity and longduration (Figure 7a), and 2) rainfall with high-intensity but short-duration (Figure 7b). During this period, twelve debris flow events have been identified according to our field survey (Table 3). The rainstorms which have been associated with debris flow occurrences have durations in the range of $21-457$ min and total rainfall larger than $17 \mathrm{~mm}$. The average intensity ranges between $4.0-49.1 \mathrm{~mm} / \mathrm{h}$. Five of the debris flow events followed rainfall of short durations $(<115 \mathrm{~min})$ and high intensities $(>14.9$ $\mathrm{mm} / \mathrm{h})$. The other seven debris flow events followed less intensive $(<10 \mathrm{~mm} / \mathrm{h})$ and relatively long-duration (115 - $457 \mathrm{~min}$ ) rainstorms. The rain gauge R01 also recorded nine rainfall events, each with total values greater than $17 \mathrm{~mm}$ that did not cause debris flow events (Table 3). These non-debris flow rainstorms generally have lower intensities $(<5 \mathrm{~mm} / \mathrm{h})$ compared to the rainfall events that generated debris flows.

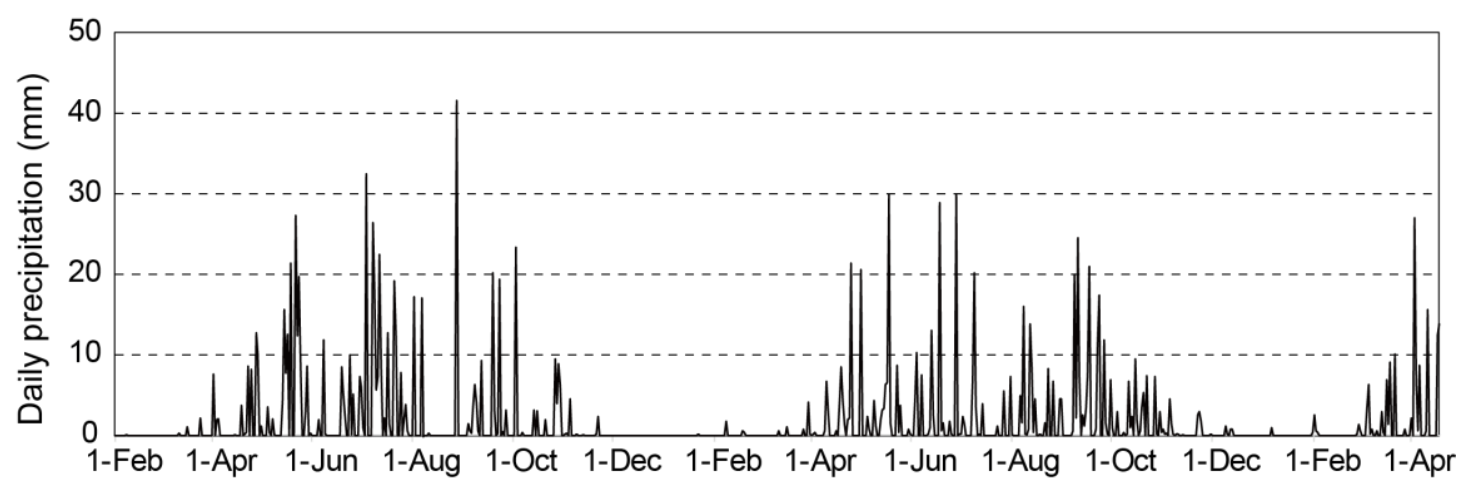

Figure 6 Daily rainfall recorded in GLP between 2013-2015 

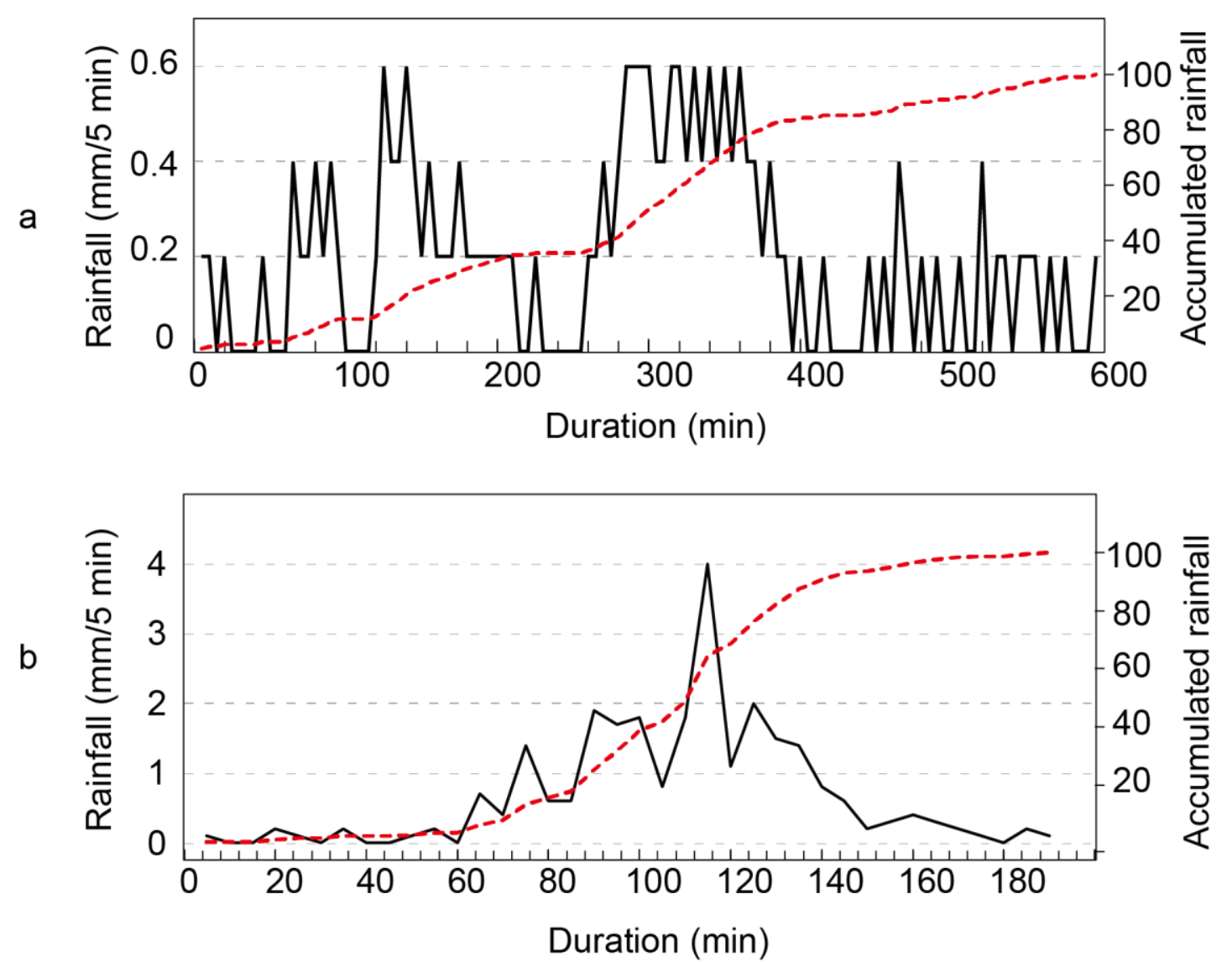

Figure 7 Two rainfall events in GLP. a. the event occurring on 2014-09-10. The rainfall persisted for 10 hours, with the maximum 5 -min total being $0.6 \mathrm{~mm}$; b. the event occurring on 2013-07-08 which persisted for only 3 hours, but with a maximum 5-min total of $4 \mathrm{~mm}$. The accumulated rainfall amount increases sharply in one hour during the rainfall period 
Table 3 Characteristics of rainfall events larger than $17 \mathrm{~mm}$ recorded during 2012-

2015 for GLP.

\begin{tabular}{cccccc}
\hline \multirow{2}{*}{$\begin{array}{c}\text { Event } \\
\text { No. }\end{array}$} & Date & Total & Duration & Intensity & Debris flow \\
\cline { 3 - 4 } & & $(\mathrm{mm})$ & $(\mathrm{min})$ & $(\mathrm{mm} / \mathrm{h})$ & occurrence \\
\hline 1 & $2012-05-11$ & 26.8 & 70 & 23.0 & Yes \\
2 & $2013-05-19$ & 21.6 & 39 & 33.2 & Yes \\
3 & $2013-05-22$ & 24.6 & 96 & 15.4 & Yes \\
4 & $2013-05-24$ & 44 & 425 & 6.2 & Yes \\
5 & $2013-07-04$ & 30.4 & 457 & 4.0 & Yes \\
6 & $2013-07-08$ & 25.8 & 190 & 8.1 & Yes \\
7 & $2013-07-12$ & 22.4 & 1360 & 1.0 & No \\
8 & $2013-07-21$ & 22.8 & 275 & 5.0 & No \\
9 & $2013-08-02$ & 17.2 & 21 & 49.1 & Yes \\
10 & $2013-08-28$ & 39.8 & 395 & 6.0 & Yes \\
11 & $2013-09-19$ & 18.8 & 250 & 4.5 & No \\
12 & $2013-10-03$ & 20.6 & 43 & 28.7 & Yes \\
13 & $2014-04-25$ & 22.4 & 375 & 3.6 & No \\
14 & $2014-05-01$ & 17.8 & 140 & 7.6 & Yes \\
15 & $2014-05-18$ & 30.2 & 440 & 4.1 & Yes \\
16 & $2014-06-18$ & 28.6 & 115 & 14.9 & Yes \\
17 & $2014-06-28$ & 27.6 & 605 & 2.7 & No \\
18 & $2014-07-09$ & 20 & 365 & 3.3 & No \\
19 & $2014-09-10$ & 24.2 & 595 & 2.4 & No \\
20 & $2014-09-17$ & 27.6 & 605 & 2.7 & No \\
21 & $2014-09-23$ & 20.4 & 490 & 2.5 & No \\
22 & $2015-04-03$ & 26.1 & 200 & 7.8 & Yes \\
\hline
\end{tabular}

361

Debris flows in the GLP valley generally caused channel-bed incision. In our field survey conducted on 2012-05-11, we observed one debris flow event that caused an average $1.5-\mathrm{m}$ incision of the channel bed (Figure $8 \mathrm{a}$ ). The peak discharge at the valley outlet (Figure 8b) was calculated based on post-event investigation. The maximum flow width and depth were estimated to be $30 \mathrm{~m}$ and $0.5 \mathrm{~m}$, respectively. The debris-flow velocity was estimated using the empirical expression that take the form of approximated Manning's equation:

$$
V=\frac{\theta^{1 / 2} y^{2 / 3}}{n}
$$

Where $\theta$ is channel gradient $(0.087), y$ is flow depth $(0.5 \mathrm{~m})$ and $n$ is roughness coefficient for debris flows (0.07) and is determined based on the characteristics of the 
channel geometry and channel-bed materials. In this study $\theta$ was measured using a laser range finder in the field, and $n$ was taken by checking the empirical table established by Kang (1987) for the region (see Supplementary material). We take a 10\% error to account for the uncertainties in determining the values for each parameter. This method derives a full-bank velocity of $2.6 \pm 0.3 \mathrm{~m} / \mathrm{s}$, and the peak discharge is estimated to be $39 \pm 7 \mathrm{~m}^{3} / \mathrm{s}$. We also analyzed a short video that was taken at the section (Figure 8c) shortly after the full-bank condition using the method of large scale particle image velocimetry (the LSPIV method $c f$. Le Bourscaud et al., 2015). The average velocity of the section (Figure $8 \mathrm{c}$ ) is estimated at $5.4 \mathrm{~m} / \mathrm{s}$, and the discharge is estimated to be 32.4 $\mathrm{m}^{3} / \mathrm{s}$ considering the flow width $(6 \mathrm{~m})$ and flow depth $(1 \mathrm{~m})$ in this section. This discharge is smaller than but close to the peak discharge value, indicating that the estimated peak discharge is broadly accurate.
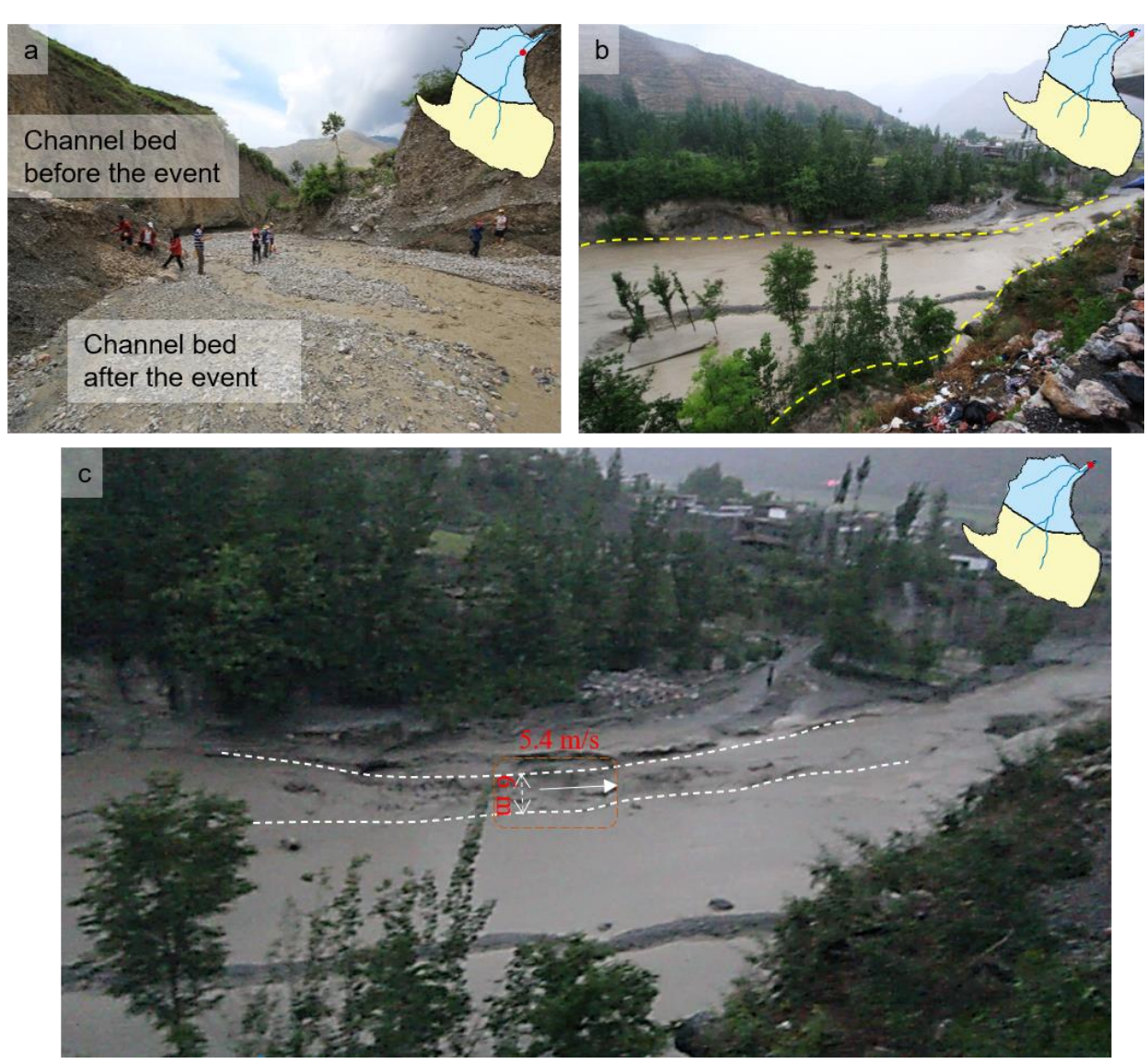

Figure 8 Photographs of the debris flow event on 2012-05-11. a) Channel bed incision caused by the event. The inset map denotes the location where the 
photograph was taken. b) Peak discharge condition of the debris flow at the valley outlet. c) the section analyzed using large scale particle image velocimetry (LSPIV). Dashed white lines confined the flow width $(6 \mathrm{~m})$ in the video, and the average flow velocity is $5.4 \mathrm{~m} / \mathrm{s}$.

\subsection{Characteristics of triggering area}

The triggering area in GLP is located in the transition area where a reverse fault forms the boundary between limestones and phyllites (Figure 9). Upstream of the fault, the limestone area of the streambed has a short section $(\sim 200 \mathrm{~m})$ with a relatively flat channel (not visible in Figure 9 due to scale). The slope of the streambed steepens higher up the valley (Figure 9), and the hillslopes are covered with trees and bushes (Figure 10). The channel in this section is lined with gravels that are predominantly derived from the limestone bedrock (Figure 11a). However, these materials are relatively difficult to entrain in flows due to the relatively gentle channel bed slope. This area is thus not considered as a debris flow initiation region, but mainly to contribute discharge for the downstream initiation of debris flows. Just downstream of the fault, the channel sees a sharp drop with an average bed slope of $24^{\circ}$ (Figure 9). Rockfalls form in the surrounding hillslopes adding loose materials to the nearby channel (Figure 10). The materials in this section are mainly composed of cobbles and boulders (Figure 11b), which are difficult to initiate. The section further downstream, with an average slope of $17^{\circ}$ (Figure 9), is identified as the triggering area of debris flows. Materials of this section are mainly of gravel size (Figures 11c\&11d), which are easier to initiate than the over-sized materials in the upper section. The computation of a triggering liquid discharge therefore focuses on this particular section. 


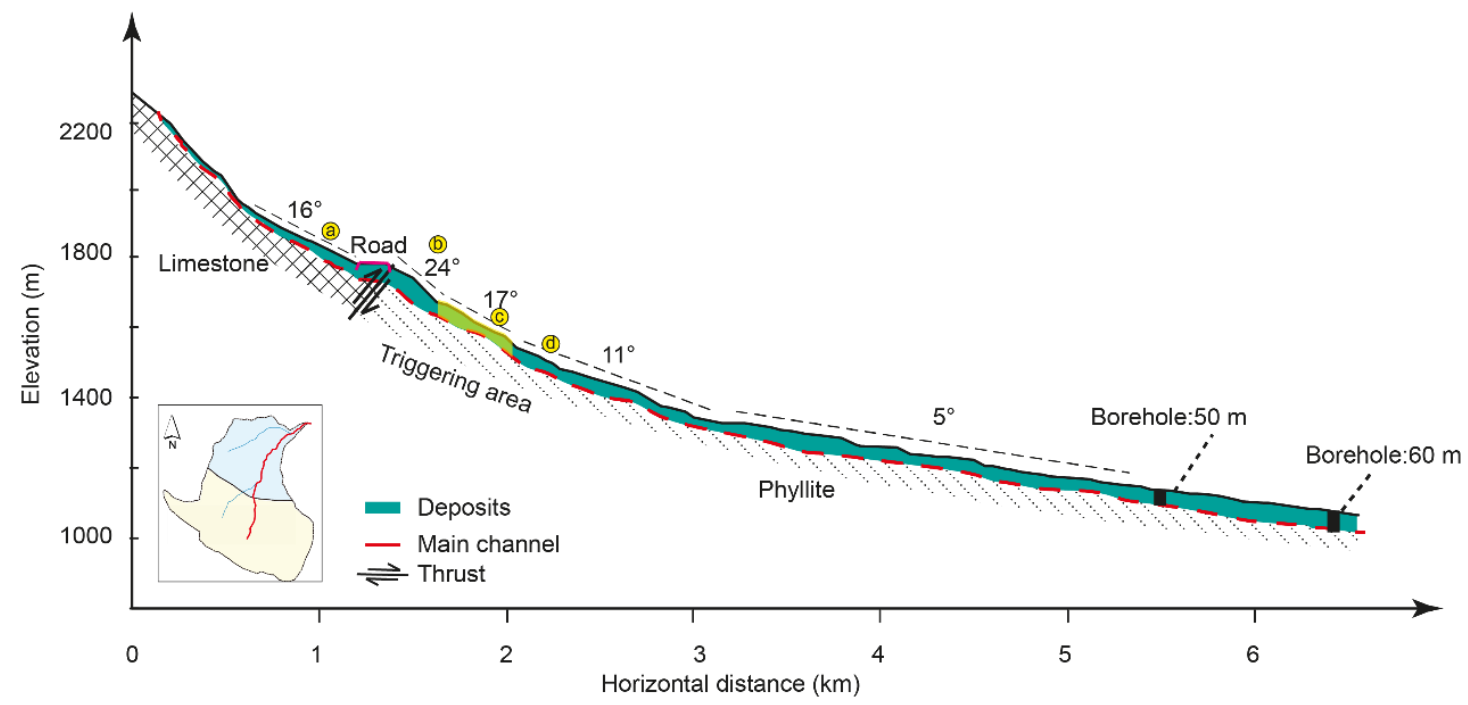

Figure 9 The longitudinal profile of the GLP channel. The area masked in blue indicates the channel bed materials. The depth of the channel bed materials was determined from two boreholes in the downstream section of the channel and is reconstructed for the remainder of the channel on the basis of interpretation of the surface morphology of the channel. The points $a, b, c, d$ are locations of the photographs presented in Figures 10 and 11. The vertical scale has been exaggerated with an exaggeration ratio of 1.9 .

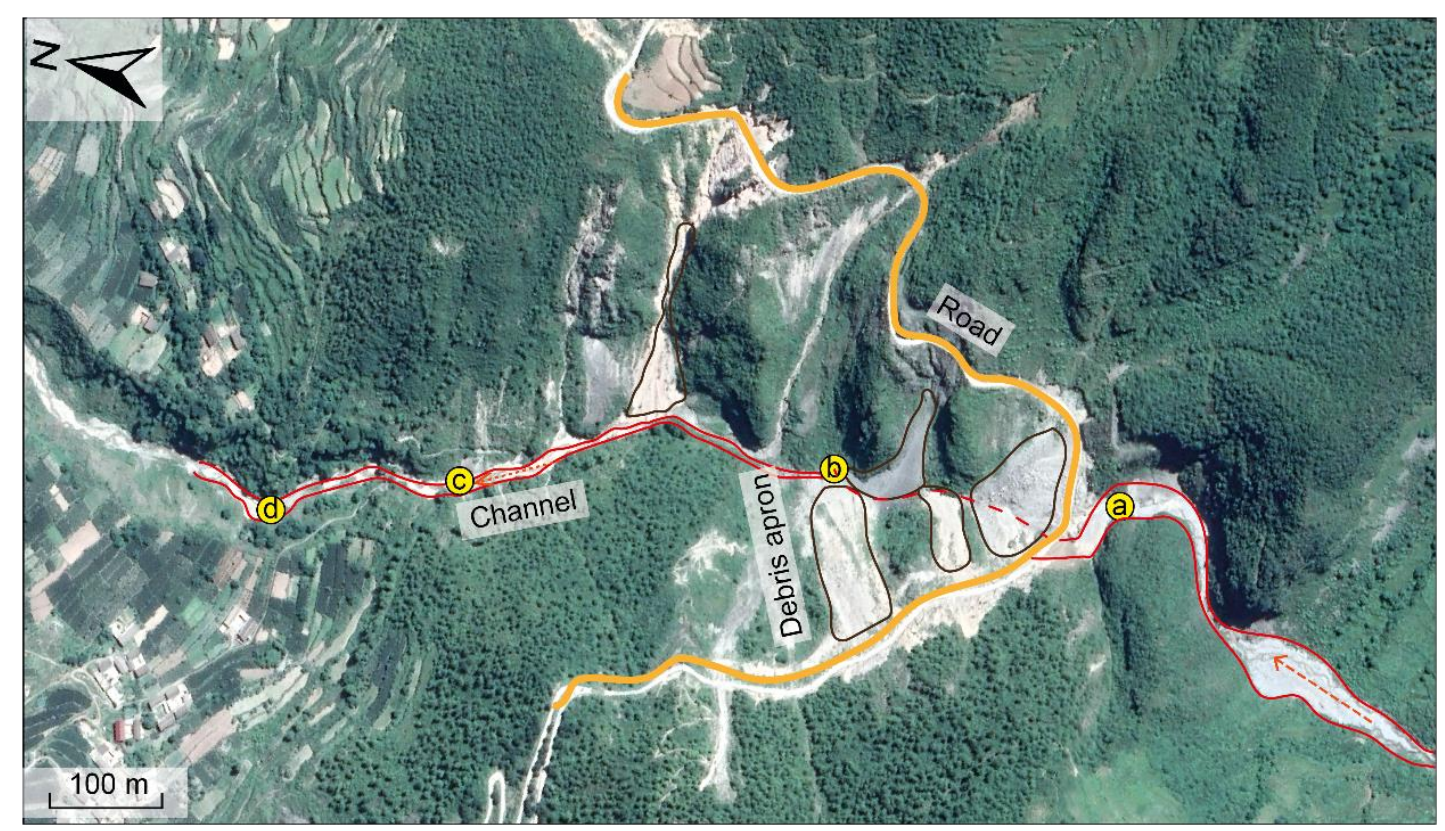

Figure 10 Satellite image of the triggering area. The main channel is denoted by the red line, and the flow direction is denoted by the red dashed lines. The black lines circle the slope screes. The points a, b, c, d are locations of the photographs presented 


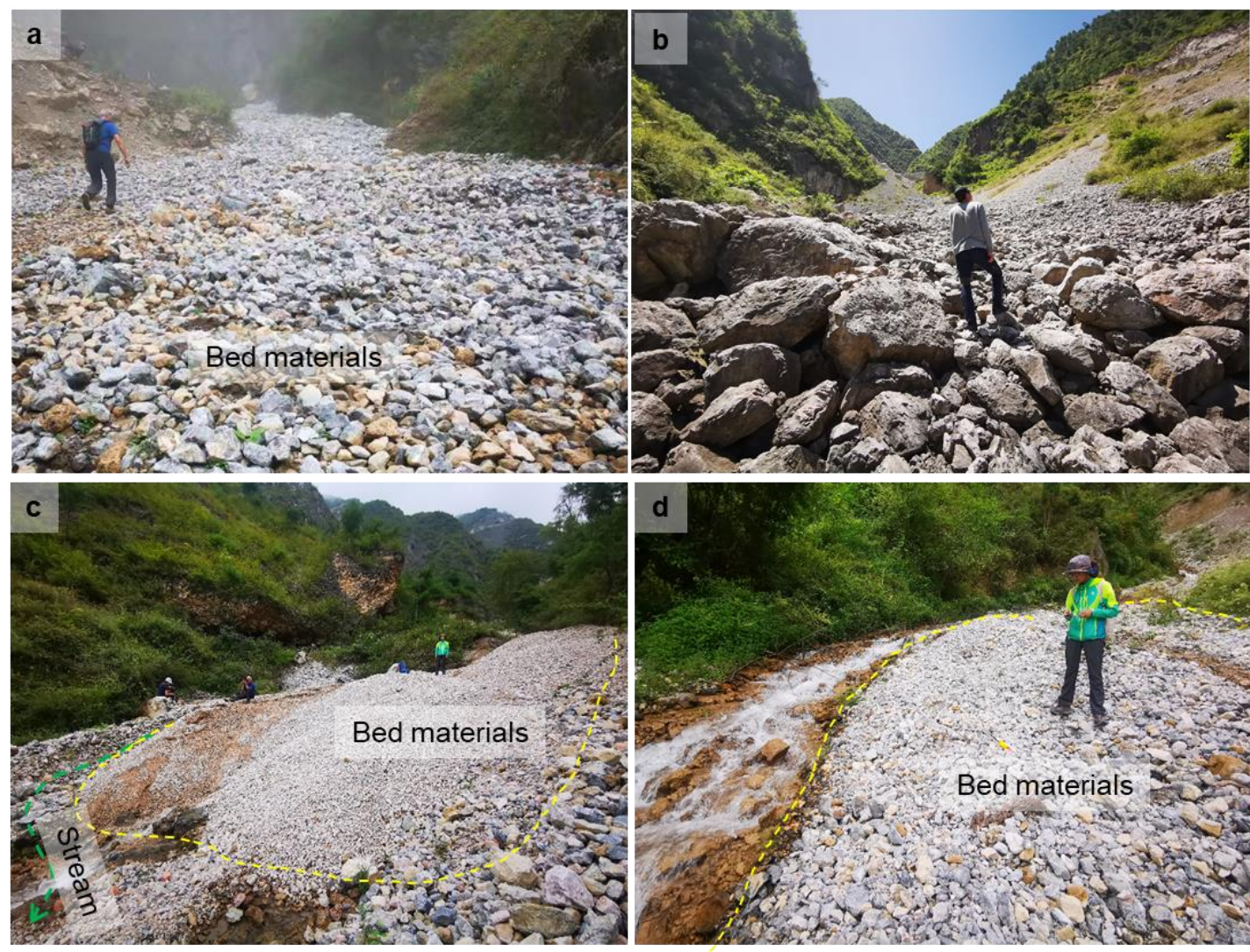

Figure 11 Photographs showing debris flow material sources in the upper part of

GLP.

\subsection{Critical discharges for debris flow initiation}

\subsubsection{Model calibration}

The hydrological model used in the study determines whether a cell is a hillslope or as channel cell, and it uses different approaches to calculate flow velocities for these cells. The channel threshold (discussed above) is calibrated using a simulation of the debris flow associated with the rainfall event of 2012-05-11. This event is presented in 436 Figure 12 (black line). It shows that the rainfall 1 started at 18:00 with very low intensities in the first 80 minutes (to 19:20). The total rainfall was $2.3 \mathrm{~mm}$ in this period

438 with an averaged intensity of $1.7 \mathrm{~mm} / \mathrm{h}$. From 19:20, the rainfall intensity increased 439 sharply for 70 minutes (to 20:25). The total rainfall in this period was $26.8 \mathrm{~mm}$ with an average intensity of $23 \mathrm{~mm} / \mathrm{h}$. After that, the rainfall intensity decreased sharply and 
continued for $110 \mathrm{~min}$ (to around 22:20). The total rainfall in this period was $4.5 \mathrm{~mm}$ with an average intensity of $2.1 \mathrm{~mm} / \mathrm{h}$. The discharge at the basin outlet increased sharply from 19:30 and the peak discharge was recorded between 20:00-20:30 because at this period all the braided channels were filled up with the flood, inundating all the levees and banks that were less than $0.5 \mathrm{~m}$ above the floodplain (Figure $8 \mathrm{~b}$ ). The peak discharge was estimated to be $39 \pm 7 \mathrm{~m}^{3} / \mathrm{s}$ as mentioned in section 3.1 . This peak discharge is a combination of debris and water discharge. We used the approach of Kang et al. (2004) (Eq.11) to extract the peak water discharge. This equation comes from a volumetric balance that assumes a constant volumetric concentration. In other words, the ratio between debris flow discharge and water discharge is equal to the ratio between the solid-liquid and liquid volumes.

$$
Q_{d}=(1+\emptyset) Q D_{d}
$$

Where $Q_{d}$ is the debris flow discharge $\left(\mathrm{m}^{3} / \mathrm{s}\right), Q$ is the water discharge $\left(\mathrm{m}^{3} / \mathrm{s}\right)$, $D_{d}$ is an empirical coefficient describing the channel blocking condition, and its value is determined according to the characteristic of the channel. For channels which are straight and wide for most sections and have a small number of narrow sections or waterfalls, $D_{d}$ is taken as 1.5 (Table 4 ). $\varnothing$ is the correction coefficient for the debris flow bulk weight defined as: $\varnothing=\left(\rho_{\mathrm{d}}-\rho_{\mathrm{w}}\right) /\left(\rho_{\mathrm{s}}-\rho_{\mathrm{d}}\right)$ : where $\rho_{d}$ is the debris flow density $\left(1.7 \mathrm{~g} / \mathrm{cm}^{3}\right)$, which was obtained by checking the empirical table for the region based on the macro-flow condition (Table 5). Local geotechnical reports for similar types of debris-flow basins also suggest that this value is reasonable. $\rho_{\mathrm{w}}$ is the density of water $\left(1 \mathrm{~g} / \mathrm{cm}^{3}\right)$, and $\rho_{\mathrm{s}}$ is the density of solid material $\left(2.65 \mathrm{~g} / \mathrm{cm}^{3}\right)$. We take a $10 \%$ error to account for the potential uncertainties related to the empirical values such as $D_{d}$ and $\rho_{d}$. This method produces a value of $15 \pm 4 \mathrm{~m}^{3} / \mathrm{s}$ for Q.

Table 4 Empirical values for different blocking conditions (Cui et al., 2011).

\begin{tabular}{|c|c|c|c|c|}
\hline $\begin{array}{c}\text { Blocking } \\
\text { coefficient }\end{array}$ & $\begin{array}{c}\text { No } \\
\text { block }\end{array}$ & Minor & Moderate & Serious \\
\hline $\mathrm{D}_{\mathrm{d}}$ & 1 & 1.5 & 2 & 2.5 \\
\hline
\end{tabular}


descriptive flow conditions (Kang et al., 2004)

\begin{tabular}{|l|c|c|c|c|}
\hline Flow density & $\begin{array}{c}\text { Very low } \\
\text { (cloudy floods) }\end{array}$ & $\begin{array}{c}\text { Low } \\
\text { (turbulence) }\end{array}$ & $\begin{array}{c}\text { Medium } \\
\text { (damped turbulence) }\end{array}$ & $\begin{array}{c}\text { High } \\
\text { (laminar flow) }\end{array}$ \\
\hline Density $\left(\mathrm{g} / \mathrm{cm}^{3}\right)$ & $1.2-1.4$ & $1.4-1.6$ & $1.6-1.8$ & $1.8-2.3$ \\
\hline
\end{tabular}

469

470

471

472

473

474

475

476

477

478

479

480

481

482

483

484

485

We input the average rainfall intensity $(23 \mathrm{~mm} / \mathrm{h})$ during the period between 19:20 and 20:25 and the associated duration (70 $\mathrm{min})$ into the model. The channel threshold was calibrated against the estimated peak water discharge of this event. The threshold value of 40 (i.e. the number of cells that contribute to the flow) produced a peak discharge of $15 \mathrm{~m}^{3} / \mathrm{s}$ (red line), and the threshold value of 10 and 120, produced the maximum $\left(19 \mathrm{~m}^{3} / \mathrm{s}\right)$ and minimum $\left(11 \mathrm{~m}^{3} / \mathrm{s}\right)$ estimates (dashed red lines), respectively. According to our observation at the valley outlet, the peak discharge condition (full bank alluviation) occurred at roughly 20:30. The modeled hydrograph for channel threshold 40 derives a roughly synchronous timing for peak discharge with the actual condition, while the hydrographs for channel threshold 10 and 120, preceded or lagged behind the peak time. It is indicated that larger channel threshold values (more hillslope cells and shorter channel distance) resulted in lower peak discharges and also longer travel times that delayed the time to peak.

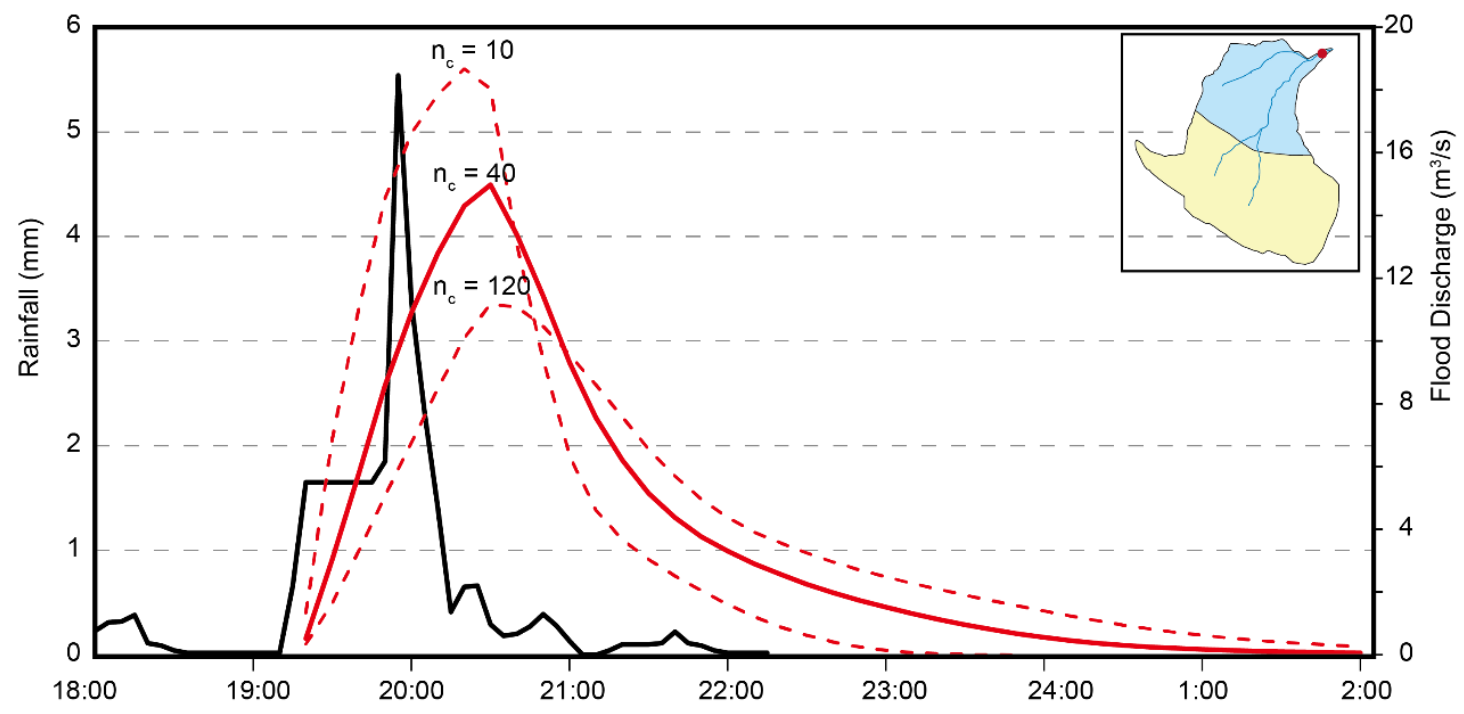

Time

Figure 12 Rainfall (black) and simulated hydrograph (red) of the rainstorm event on 2012-05-11. $\mathrm{n}_{\mathrm{c}}$ is the channel threshold. 
487

488

489

490

491

492

493

494

495

496

497

498

499

500

501

502

503

504

505

506

507

508

509

510

511

512

513

514

To determine the critical discharges for debris flow initiation, we simulate the peak discharges at the valley triggering section for the recorded rainfall events. We used the 22 rainfall events (each having a total rainfall of at least $17 \mathrm{~mm}$ ) recorded in the valley, including all thirteen observed debris flow events and nine non-debris flow events. The total rainfall duration and average intensity are used as model input, and the peak discharges are simulated under the three model setups (i.e. $\mathrm{n}_{\mathrm{c}}=10,40$ and 120). The result is presented in Table 6 and Figure 13. Here we determine two types of critical discharges: the upper limit (UL) of peak discharges that do not cause debris flows, and the lower limit (LL) of peak discharges that initiate debris flows (Cannon et al., 2008). The LL critical discharges are $0.09,0.21$ and $0.26 \mathrm{~m}^{3} / \mathrm{s}$ for channel thresholds being 120, 40 and 10, respectively. The UL critical discharges are $0.38,0.40$ and $0.51 \mathrm{~m}^{3} / \mathrm{s}$ for channel thresholds being 120, 40 and 10, respectively (Table 6). The empirical critical discharges calculated in section 2.3 are also shown in Figure 13. Takahashi's (1978) expression produces a critical discharge $\left(\mathrm{Q}_{\mathrm{Tak}}\right)$ of $0.51 \pm 0.2 \mathrm{~m}^{3} / \mathrm{s}$. This value approaches the UL critical discharges but has a large error range. The expression by Tognacca et al. (2000) produces a critical discharge $\left(\mathrm{Q}_{\mathrm{Tog}}\right)$ of $0.36 \pm 0.06 \mathrm{~m}^{3} / \mathrm{s}$ that is equivalent to the lower value of $\mathrm{Q}_{\mathrm{Tak}}$ and has a smaller error range than that of $\mathrm{Q}_{\mathrm{Tak}}$. The expression by Gregoretti and Dalla Fontana (2008) produces a theoretical value of 0.08 $\pm 0.01 \mathrm{~m}^{3} / \mathrm{s}$. This value is smaller than the LL critical discharges for the three model setups. The expression by Lamb et al (2008) produces a theoretical value of $0.15 \pm 0.05$ $\mathrm{m}^{3} / \mathrm{s}$, which is smaller than the LL discharges for model setups of $\mathrm{n}_{\mathrm{c}}=10$ and $\mathrm{n}_{\mathrm{c}}=40$. Overall, comparison of the empirical critical discharges and the critical discharges defined by the dataset suggests that the expressions by Takahashi (1978) and Tognacca et al (2000) produce discharges that approach the UL critical discharges, while the expressions by Gregoretti and Dalla Fontana (2008) and Lamb et al (2008) produce discharges that approach the LL critical discharges. This result is expected because the expressions of Gregoretti and Dalla Fontana (2008) and Lamb et al. (2008) concern the limit initiation of a debris flow while that of Tognacca et al (2000) concerns the 
515 initiation of a fully developed debris flow. The expression by Takahashi (1978) provides

516 a critical discharge larger than those of Gregoretti and Dalla Fontana (2008) and Lamb

517 et al. (2008) because the triggering mechanism concerns the failure of the whole mass

518 of channel bed materials contributing to a debris flow, rather than just the erosion of

519 surficial layers (Gregoretti, 2000).

520

521 Table 6 Simulated peak discharges at the triggering section corresponding to

522 different cell numbers $\left(\mathrm{n}_{\mathrm{c}}\right)$.

\begin{tabular}{cccc}
\hline Event & $\mathrm{Q}_{\mathrm{p}}\left(\mathrm{m}^{3} / \mathrm{s}\right)$ & $\mathrm{Q}_{\mathrm{p}}\left(\mathrm{m}^{3} / \mathrm{s}\right)$ & $\mathrm{Q}_{\mathrm{p}}\left(\mathrm{m}^{3} / \mathrm{s}\right)$ \\
\cline { 2 - 4 } No. & $\mathrm{n}_{\mathrm{c}}=10$ & $\mathrm{n}_{\mathrm{c}}=40$ & $\mathrm{n}_{\mathrm{c}}=120$ \\
\hline 1 & 2.65 & 1.56 & 0.97 \\
2 & 1.65 & 0.65 & 0.46 \\
3 & 1.59 & 0.81 & 0.60 \\
4 & 2.01 & 1.99 & 1.91 \\
5 & 0.76 & 0.71 & 0.66 \\
6 & 1.10 & 0.83 & 0.55 \\
7 & 0.10 & 0.10 & 0.09 \\
8 & 0.51 & 0.35 & 0.27 \\
9 & 0.71 & 0.27 & 0.16 \\
10 & 1.73 & 1.68 & 1.57 \\
11 & 0.24 & 0.14 & 0.10 \\
12 & 1.19 & 0.56 & 0.32 \\
13 & 0.36 & 0.25 & 0.22 \\
14 & 0.26 & 0.21 & 0.09 \\
15 & 0.78 & 0.76 & 0.66 \\
16 & 2.29 & 1.24 & 1.08 \\
17 & 0.44 & 0.4 & 0.38 \\
18 & 0.23 & 0.17 & 0.12 \\
19 & 0.30 & 0.27 & 0.24 \\
20 & 0.44 & 0.40 & 0.38 \\
21 & 0.19 & 0.16 & 0.12 \\
22 & 1.09 & 0.81 & 0.57 \\
\hline
\end{tabular}

523 

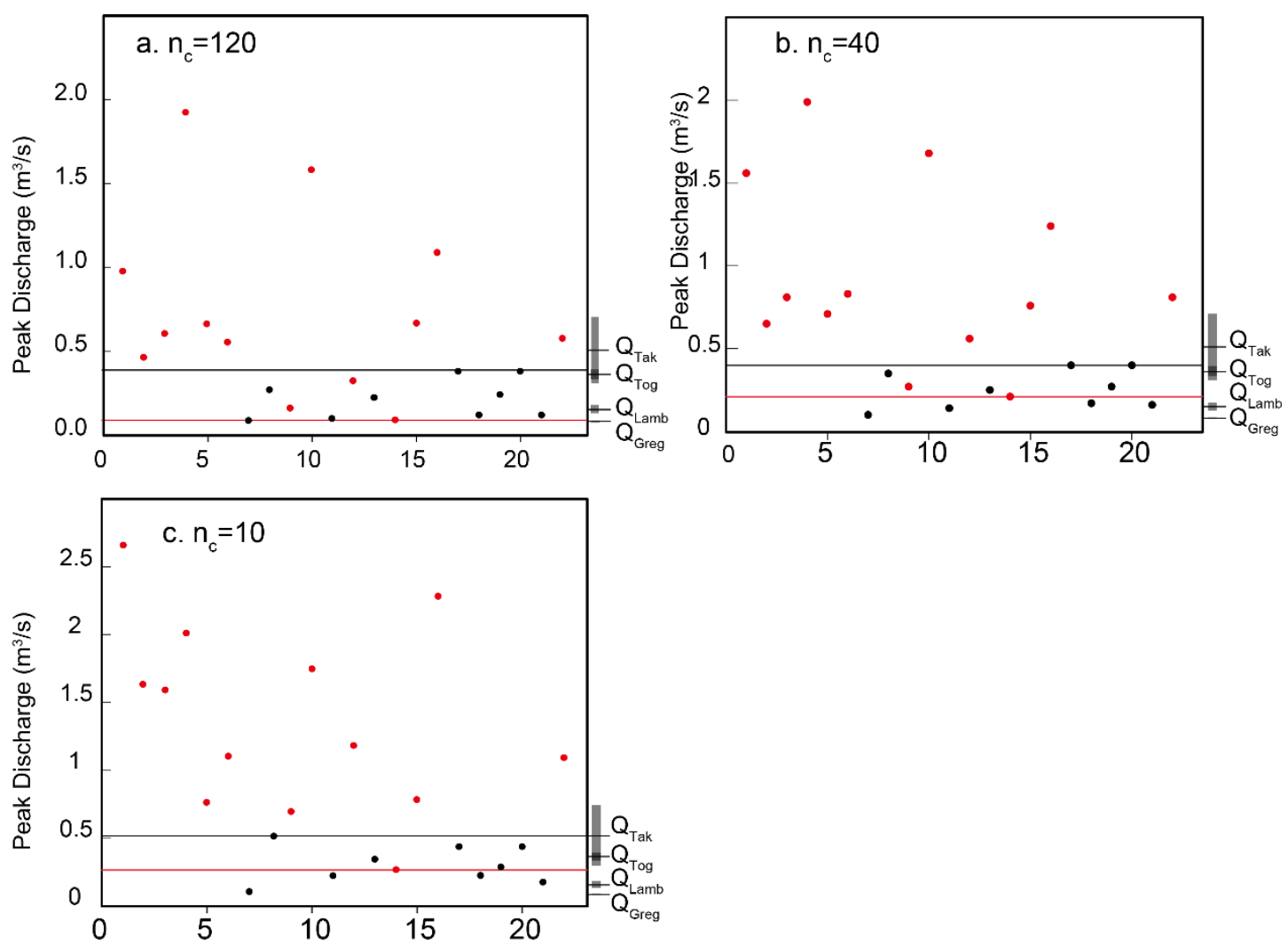

Figure 13 Simulated peak discharges of different rainfall events at the triggering section of the valley. Panels $\mathrm{a}, \mathrm{b}$ and $\mathrm{c}$ are the estimated results corresponding to different channel thresholds. The horizontal axis represents the event sequence listed in Table 2. Red dots are rainfall events with debris flow occurrence, while black dots are rainfall events without. The red lines are the LL critical discharges, while the black lines are the UL critical discharges. $\mathrm{Q}_{\text {Tak, }}, \mathrm{Q}_{\mathrm{Tog}}, \mathrm{Q}_{\mathrm{Lamb}}$ and $\mathrm{Q}_{\mathrm{Greg}}$ are the critical discharges by the expressions by Takahashi (1978), Tognacca et al. (2000), Lamb et al. (2008) and Gregoretti and Dalla Fontana (2008), respectively. The grey bars are the error range for the respective critical discharge. These errors are propagated errors

\subsection{Construction of I-D thresholds based on critical discharges and S-hydrographs}

This paper attempts to test whether a power-law function can be established among peak discharge, rainfall intensity and duration, such that a conventional power-law I-D threshold can be established. Our hydrological simulation produced unit-time hydrographs for recorded rainfall events. These hydrographs can be transformed into 
542 S-hydrographs displaying the relation between unit cumulative runoff and time. These

543 diagrams show similar "S" shaped patterns except that the magnitudes and the times

544 reaching the plateaus are different (Figure 14a). Here we simulated the S-hydrographs

545 for the 22 recorded rainfall events under the model setup of $n_{c}=40$ (Table 7). The rising

546 limbs of the "S" shaped curves (the first 3 hours) can be approximated using a power-

547 law function:

$548 \quad R(t)=a \times t^{b}$

$549 \quad(12)$

550 Where $R(\mathrm{t})$ is the cumulative runoff $\left(\mathrm{m}^{3} / \mathrm{s}\right)$ on the S-hydrograph, $t$ is time $(\mathrm{h}) . a$

551 is the fitted coefficient describing the magnitude of each curve and varies with rainfall

552 intensity and duration (Table 7); $b$ is the power coefficient describing the general

553 pattern of each curve and is a constant for all curves (Table 7).

554 Table 7 Rainfall events and fitted coefficients for the rising limbs of S-hydrographs.

\begin{tabular}{cccc|ccc}
\hline \multicolumn{4}{c}{ Rainfall characteristics } & \multicolumn{3}{c}{ Fitted coefficients } \\
\hline Event & Date & $\begin{array}{c}\text { Duration } \\
\text { No. }\end{array}$ & $\begin{array}{c}\text { Intensity } \\
(\mathrm{mm} / \mathrm{h})\end{array}$ & $\mathrm{a}$ & $\mathrm{b}$ & $\mathrm{R}^{2}$ \\
\hline 1 & $2012-5-11$ & 1.2 & 23 & 1.424 & 0.75 & 0.99 \\
2 & $2013-5-19$ & 0.7 & 33.2 & 1.205 & 0.75 & 0.99 \\
3 & $2013-5-22$ & 1.6 & 15.4 & 0.686 & 0.75 & 0.99 \\
4 & $2013-05-24$ & 7.1 & 6.2 & 0.716 & 0.75 & 0.99 \\
5 & $2013-07-04$ & 7.6 & 4 & 0.207 & 0.75 & 0.99 \\
6 & $2013-07-08$ & 3.2 & 8.1 & 0.348 & 0.75 & 0.99 \\
7 & $2013-07-12$ & 22.7 & 1 & 0.015 & 0.75 & 0.97 \\
8 & $2013-07-21$ & 4.6 & 5 & 0.128 & 0.75 & 0.99 \\
9 & $2013-08-02$ & 0.4 & 49.1 & 0.75 & 0.75 & 0.99 \\
10 & $2013-08-28$ & 6.6 & 6 & 0.592 & 0.75 & 0.99 \\
11 & $2013-09-19$ & 4.2 & 4.5 & 0.054 & 0.75 & 0.99 \\
12 & $2013-10-03$ & 0.7 & 28.7 & 0.849 & 0.75 & 0.99 \\
13 & $2014-04-25$ & 6.3 & 3.6 & 0.078 & 0.75 & 0.99 \\
14 & $2014-05-01$ & 2.3 & 7.6 & 0.082 & 0.75 & 0.99 \\
15 & $2014-05-18$ & 7.3 & 4.1 & 0.213 & 0.75 & 0.99 \\
16 & $2014-06-18$ & 1.9 & 14.9 & 0.973 & 0.75 & 0.99 \\
17 & $2014-06-28$ & 10.1 & 2.7 & 0.101 & 0.75 & 0.99 \\
18 & $2014-07-09$ & 6.1 & 3.3 & 0.047 & 0.75 & 0.99 \\
19 & $2014-09-10$ & 9.9 & 2.4 & 0.061 & 0.75 & 0.99 \\
20 & $2014-09-17$ & 10.1 & 2.7 & 0.101 & 0.75 & 0.99 \\
21 & $2014-09-23$ & 8.2 & 2.5 & 0.035 & 0.75 & 0.99 \\
22 & $2015-04-03$ & 3.3 & 7.8 & 0.341 & 0.75 & 0.99 \\
\hline
\end{tabular}



durations (D), we fit coefficient ' $a$ ' with the characteristic I and D using a power-law function (Eq. 13 and Figure 14b).

$$
a=k \times I^{m} \times D^{n}
$$

Where $\mathrm{m}=4.0, \mathrm{n}=2.7$, and $\mathrm{k}=3.3 \times 10^{-6}$, with $\mathrm{R}^{2}=0.96$. Combining Equations 12 and 13, the unit cumulative discharge $(R(t))$ at a given time $t$ is expressed as:

$$
R(t)=k \times I^{m} \times D^{n} \times t^{b}
$$
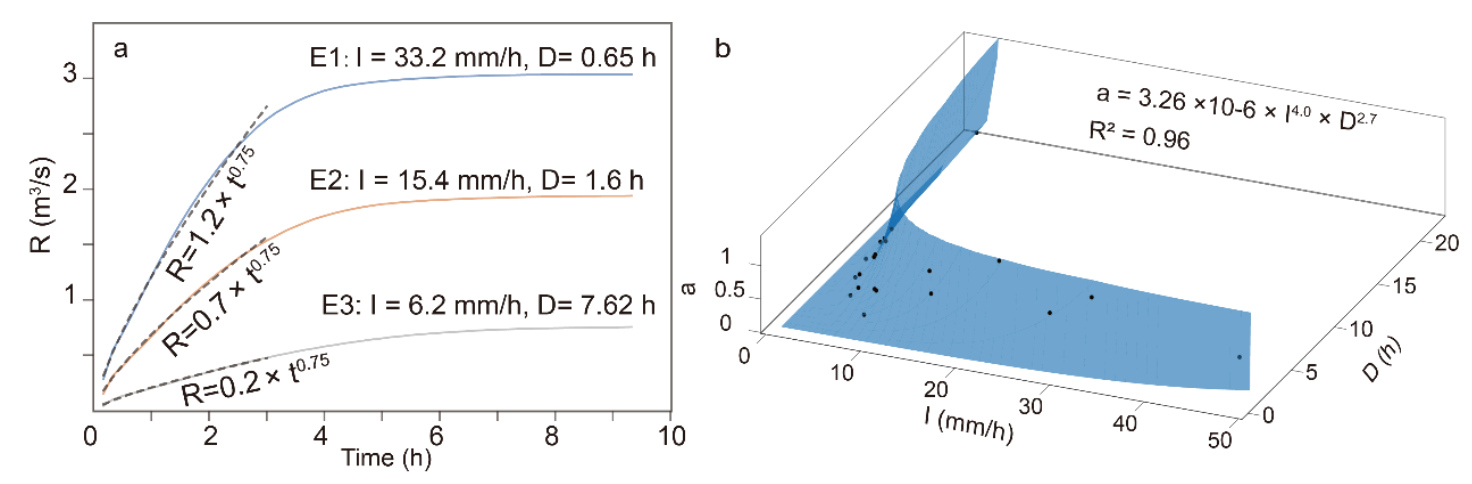

Figure 14 Mathematical relations among rainfall duration (D), intensity (I), peak discharges and unit cumulative runoff. a. The unit cumulative hydrographs for three rainfall events occurring on 2013-05-19 (E1), 2013-05-22 (E2) and 2013-07-04 (E3). The dashed lines are the fitted relation between each S-hydrograph and time for the first 3 hours. b. The fitted relation between coefficient ' $a$ ' and (I, D).

The unit-time hydrograph $(\mathrm{h}(\mathrm{t}))$ for the GLP valley is presented in Figure 15. According to this hydrograph, the unit cumulative discharge $(R(t))$ can be described as:

$$
R(t)=\sum_{1}^{t} h(t)
$$

The peak discharge $\left(R_{p}\right)$ for a rainfall event with a given duration (D) can be expressed as:

$$
R_{p}=\left\{\begin{array}{r}
h(2), D=1 \\
\sum_{1}^{D} h(t), D>1
\end{array}\right.
$$

Combining equations 14,15 and 16, the peak discharge for a rainfall event with its duration larger than one unit-time (10 $\mathrm{min})$ can be expressed as:

$$
R_{p}=R(D)=k \times I^{m} \times D^{n} \times D^{b}
$$




$$
I=\left(\frac{R_{p}}{k}\right)^{\frac{1}{m}} \times D^{-\left(\frac{n+b}{m}\right)}
$$

582

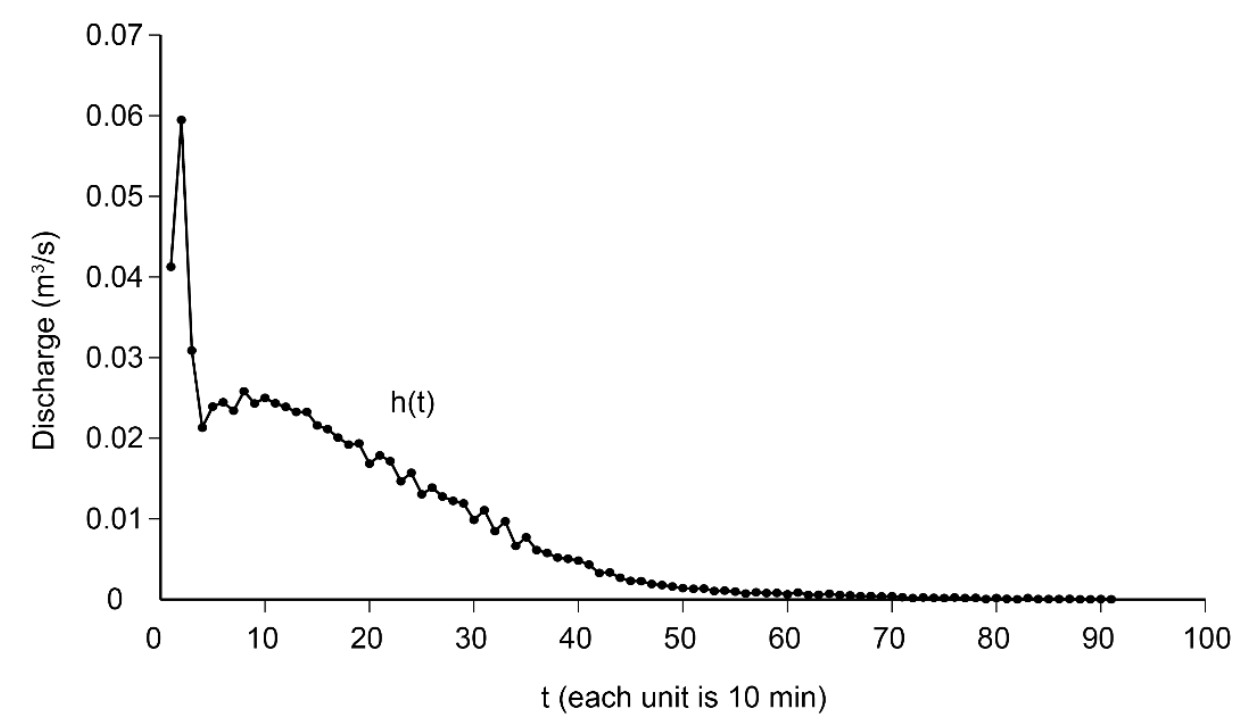

583

584

585

586

587

588

589

590

591

592

593

594

595

596

597

The rainfall I-D thresholds for debris flow initiation in the GLP valley are produced by inputting the process-based critical discharges by the expressions by Takahashi (1978), Tognacca et al. (2000), Lamb et al. (2008), and Gregoretti and Dalla Fontana (2008) into Equation 18.

$$
\begin{aligned}
& I=20.3 D^{-0.87} \\
& I=18.6 D^{-0.87} \\
& I=14.9 D^{-0.87} \\
& I=12.7 D^{-0.87}
\end{aligned}
$$

These constructed I-D thresholds are compared with the observational data in the GLP valley and other empirically-based I-D thresholds (Figure 16). 


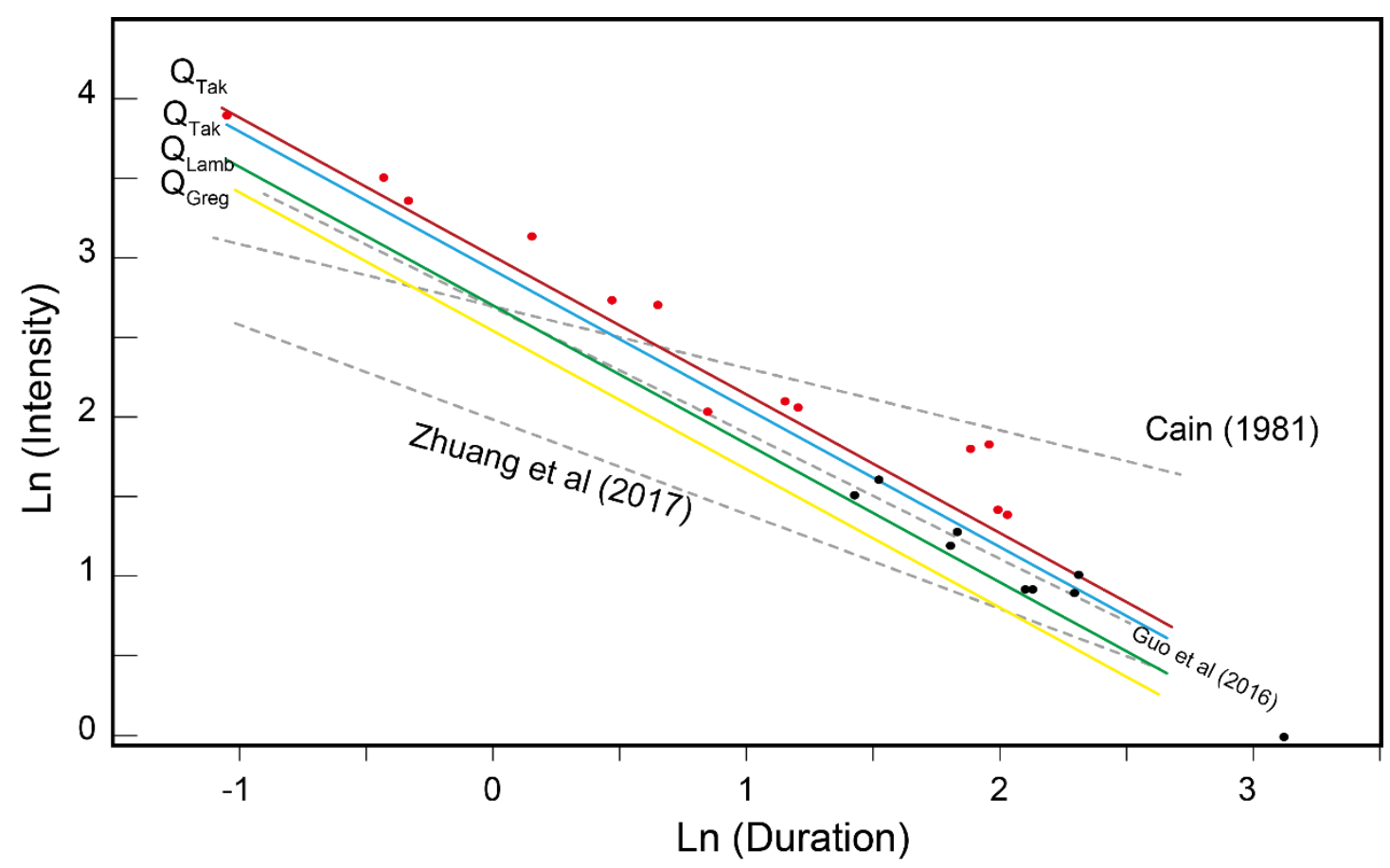

598

599

600

601

602

603

604

605

606

607

608

609

610

611

612

613

614

615

616

Figure 16 Comparison of different I-D thresholds. Solid lines are the I-D thresholds constructed based on the four theoretical discharges derived in this study. Dashed lines are empirical I-D thresholds for other areas. Red dots are rainfall events with debris flow occurrence, while black dots are rainfall events with no debris flow occurrence in the GLP valley

\section{Discussion}

\subsection{Critical discharges for debris flow initiation}

This paper simulates peak discharge at the debris flow initiation area for debris flow and non-debris flow rainfall events using a spatially distributed travel time hydrological model. The study valley has a rain gauge recording the rainfall events, however, no equipment for runoff has been installed. As a result, the channel threshold $\left(\mathrm{n}_{\mathrm{c}}\right)$ is difficult to obtain. Field observations and video analysis of a debris flow event occurring on 2012-05-11 enabled calculation of peak discharge $\left(39 \pm 7 \mathrm{~m}^{3} / \mathrm{s}\right)$. An empirical approach was then used to derive the corresponding peak water discharge (15 $\pm 4 \mathrm{~m}^{3} / \mathrm{s}$ ). Further analysis of peak discharge and recorded rainfall results in obtaining the channel threshold parameter $n_{c}$, i.e. the critical number of contributing cells upstream $\left(n_{c}=40\right)$. The sensitivity of $n_{c}$ to estimates of peak water discharge is presented 
621

in Table 8. This peak water discharge decreases with an increase in channel thresholds, and the conditions of $n_{c}=10$ and $n_{c}=120$ are used to derive the maximum and minimum estimates of peak water discharge of debris flow events, respectively.

Table 8 Sensitivity analysis of $n_{c}$ to peak discharges

\begin{tabular}{cc}
\hline $\mathrm{n}_{\mathrm{c}}$ & discharge $\left(\mathrm{m}^{3} / \mathrm{s}\right)$ \\
\hline 10 & 18.7 \\
20 & 16.5 \\
40 & 15 \\
60 & 13.6 \\
80 & 12.7 \\
100 & 11.9 \\
120 & 11.2 \\
\hline
\end{tabular}

Using three channel thresholds $(10,40,120)$ we have simulated peak discharges for 22 observed rainfall events at the triggering section of the valley (Figure 13). The results confirm that most debris flow events have a larger peak discharge than those for non-debris flow events. Following the method by Cannon et al (2008), we determined the LL and the UL critical discharges for the observed 22 rainfall events. To test which one can best define the threshold, we compared the rates of false positive and false negative errors (Staley et al., 2013). The result is presented in Table 9. The LL critical discharges produce 0 false negative errors but have a high rate of false positive errors (more than 55\%) for the dataset presented. In contrast, the UL critical discharges have 0 false-positive errors and small rates of false negative errors (8-23\%) for the dataset presented. From this analysis, the UL critical discharges may be better to define the critical discharges for the study valley.

Table 9 Critical discharges for different model setups and predicting efficiency

\begin{tabular}{c|c|c|c}
\hline & $\begin{array}{c}\text { Critical discharge } \\
\left(\mathrm{m}^{3} / \mathrm{s}\right)\end{array}$ & $\begin{array}{c}\text { False } \\
\text { negative }\end{array}$ & $\begin{array}{c}\text { False } \\
\text { positive }\end{array}$ \\
\hline LL $\left(\mathrm{n}_{\mathrm{c}}=10\right)$ & 0.26 & 0 & $55.50 \%$ \\
\hline LL $\left(\mathrm{n}_{\mathrm{c}}=40\right)$ & 0.21 & 0 & $55.50 \%$ \\
\hline LL $\left(\mathrm{n}_{\mathrm{c}}=120\right)$ & 0.09 & 0 & $100 \%$ \\
\hline $\mathrm{UL}\left(\mathrm{n}_{\mathrm{c}}=10\right)$ & 0.51 & $7.70 \%$ & 0 \\
\hline $\mathrm{UL}\left(\mathrm{n}_{\mathrm{c}}=40\right)$ & 0.4 & $15.40 \%$ & 0 \\
\hline $\mathrm{UL}\left(\mathrm{n}_{\mathrm{c}}=120\right)$ & 0.38 & $23.10 \%$ & 0 \\
\hline
\end{tabular}


The empirical critical discharges for debris flow initiation at the triggering area of GLP are calculated using the four expressions by Takahashi (1978), Tognacca et al. (2000), Lamb et al. (2008) and Gregoretti and Dalla Fontana (2008), denoted as Q Tak, $\mathrm{Q}_{\text {Tog, }} \mathrm{Q}_{\mathrm{Lamb}}$ and $\mathrm{Q}_{\text {Greg }}$ respectively. Our result shows that $\mathrm{Q}_{\text {Tak }}\left(0.51 \pm 0.2 \mathrm{~m}^{3} / \mathrm{s}\right)$ by Takahashi (1978) is the largest and has the largest value of uncertainty $\left( \pm 0.2 \mathrm{~m}^{3} / \mathrm{s}\right)$ among the four values. The reason for the large error of $\mathrm{Q}_{\mathrm{Tak}}$ is because the calculation of $\mathrm{Q}_{\mathrm{Tak}}$ needs more parameters (such as the densities of solid and water, the friction angles, and the volume concentration of solid materials) than the other three approaches. The large error range of $\mathrm{Q}_{\mathrm{Tak}}$ produces critical discharges that are between $0.31-0.71$ $\mathrm{m}^{3} / \mathrm{s}$, and the upper range $\left(0.51-0.71 \mathrm{~m}^{3} / \mathrm{s}\right)$ is higher than the UL critical discharges, suggesting that the approach by QTak may not be able to provide safe critical discharges for debris flow initiation.

$\mathrm{Q}_{\mathrm{Tog}}\left(0.36 \pm 0.06 \mathrm{~m}^{3} / \mathrm{s}\right)$ falls within the lower range of $\mathrm{Q}_{\mathrm{Tak}}$ but has a smaller error than that of $\mathrm{Q}_{\text {Tak. }}$ This value approaches the UL critical discharges for the three model setup conditions and is suggested defining the UL critical discharges for debris flow initiation. QLamb $\left(0.15 \pm 0.05 \mathrm{~m}^{3} / \mathrm{s}\right)$ and $Q_{\text {Greg }}\left(0.08 \pm 0.01 \mathrm{~m}^{3} / \mathrm{s}\right)$ are the two lowest values of critical discharge and approach the LL critical discharges. $Q_{\text {Greg }}$ is below the smallest LL critical discharges, suggesting that the approach by Gregoretti and Dalla Fontana (2008) can provide the most conservative critical discharges for debris flow initiation.

\subsection{Construction of rainfall I-D threshold for debris flow initiation}

This paper constructs the rainfall I-D thresholds for debris flow initiation based on process-based critical discharges and the approximated mathematical relation between peak discharge and rainfall intensity and duration. This mathematical relation is constructed by analyzing the characteristics of the S-hydrographs that are produced by a spatially distributed hydrological model. This paper used the recorded rainfall events to obtain the required fitting coefficients. In practice, theoretical rainfall events with different combinations of intensity and duration can be used to determine the coefficients as long as hydrological models are established.

We derive four I-D thresholds (Figure 16) based on the process-based critical 
681

discharges by Takahashi (1978), Tognacca et al. (2000), Lamb et al. (2008), and Gregoretti and Dalla Fontana (2008). The threshold derived by the critical discharge of Takahashi (1978) can separate 11 of the 13 observed debris-flow events, thus having a $15 \%$ false negative rate (Table 10 ). At the same time, this threshold only mistakenly classifies one of the nine non-debris-flow events into a debris-flow event, thus having an $11 \%$ false positive rate. The threshold derived by the critical discharge of Tognacca et al. (2000) has a similar efficiency in predicting debris flow events to that of Takahashi (1978). In contrast, the thresholds by the expressions by Lamb et al (2008) and Gregoretti and Dalla Fontana (2008) can identify all debris flow events but also wrongly categorize all non-debris-flow events into debris-flow events, thus having a 0 false negative rate but a $100 \%$ false positive rate. Overall it can be concluded that none of the thresholds are perfect in distinguishing debris flow from non-debris flow events for the study valley, but our approach is able to produce various thresholds that can contribute to more regionally specific risk management of debris flow valleys.

Table 10 Predictive efficiency of debris flow events for different I-D thresholds derived in this study and empirical thresholds in other regions.

\begin{tabular}{l|l|l|l}
\hline Critical discharge & I-D threshold & False-negative & False-positive \\
\hline Takahashi (1978) & $I=20.3 D^{-0.87}$ & $15 \%$ & $11 \%$ \\
\hline Tognacca et al. (2000) & $I=18.6 D^{-0.87}$ & $8 \%$ & $11 \%$ \\
\hline Lamb et al. (2008) & $I=14.9 D^{-0.87}$ & 0 & $100 \%$ \\
\hline $\begin{array}{l}\text { Gregoretti and Dalla } \\
\text { Fontana (2008) }\end{array}$ & $I=12.7 D^{-0.87}$ & 0 & $100 \%$ \\
\hline Cain (1981) & $I=14.8 D^{-0.37}$ & $54 \%$ & 0 \\
\hline Guo et al (2016) & $I=14.7 D^{-0.79}$ & 0 & $44 \%$ \\
\hline Zhuang et al (2017) & $I=7.3 D^{-0.59}$ & 0 & $88 \%$ \\
\hline
\end{tabular}

Some researchers have produced I-D thresholds based on critical discharges and hydrological models. For example, Berti and Simoni (2005) produced an I-D threshold using a hydrological model. The threshold was drawn based on many calculations of 
idealized rainstorms. Tang et al. (2019) derived physically-based I-D thresholds by repeatedly running model simulation to different idealized rainfalls. Therefore, both methods provide numerical approximations of the rainfall threshold. The method proposed in this study is rooted in the mathematical relations among rainfall intensity, duration and peak discharges. Consequently, an analytical rainfall threshold is derived. The advantage of this method is that it does not require many calculations, and the threshold can be applied to a continuous range of rainfall duration. It is noteworthy that the accuracy of this method depends on how closely the power function fits the curve of the S-hydrograph, which is determined by watershed shape, drainage pattern and land-use, amongst other factors. The key steps used in this method include the characterization of the hydrologic soil-cover complexes, to determine the $\mathrm{CN}$ value, the determination of the model parameter $n_{\mathfrak{c}}$, and the calculation of process-based critical discharges for debris flow initiation. Except for the model parameter $\mathrm{n}_{\mathfrak{c}}$, other parameters can be obtained by field investigation, interpretation of remote-sensing images and simple field measurements such as grain size measurement and infiltration tests. Consequently, this method is efficient to apply in practice, though more efforts should be focused on the determination of the most suitable $n_{c}$ value.

\section{Conclusions}

In this study, peak discharges at the triggering area of a typical debris flow valley along the Bailong River are calculated for debris flow and non-debris flow events. Comparisons of the simulated peak discharges indicate that the UL critical discharges can predict $77-92 \%$ of the observed debris flow events while keeps a small rate of false negative errors (8-23\%). In contrast, the LL critical discharges can predict all observed debris flow events but have a high rate of false positive errors (more than 55\%). We therefore suggest that the UL critical discharges may be better to define the critical conditions for the study valley.

The theoretical critical discharges are calculated using the approaches of Takahashi (1978), Tognacca et al. (2000), Lamb et al. (2008) and Gregoretti and Dalla Fontana (2008). The approaches of Takahashi (1978) and Tognacca et al. (2000) produce critical 
discharges that approach the UL critical discharges. As the approach by Takahashi (1978) produces large errors, we suggest using the approach of Tognacca et al. (2000) to determine the UL critical discharges. In contrast, the expressions of Lamb et al. (2008) and Gregoretti and Dalla Fontana (2008) produce values that approach the LL critical discharges.

Further, we present a method for constructing rainfall I-D thresholds based on process-based critical discharges and the approximated relation between peak discharge and rainfall duration and intensity. The critical discharge by Takahashi's (1978) expression allows us to construct an I-D threshold curve that delimits debris flow events and non-debris flow events in the GLP valley with a 15\% false-negative rate and an 11\% false-positive rate. The I-D threshold of Tognacca et al (2000) produces equivalent false-negative rates and false-positive rates to that of Takahashi (1978). In contrast, the I-D thresholds of Lamb et al (2008) and Gregoretti and Dalla Fontana (2008) produce 0 false-negative rates but $100 \%$ false-positive rates. We suggest that these I-D thresholds can be used to issue early warnings through appropriate communication and full recognition of the uncertainties associated with these thresholds. This method does not require long-term observational data of rainfall and debris flows, and all one needs to do is to collect data from a catchment through image interpretation and field survey. Therefore, this method can be applied to areas where historical data are unavailable.

\section{Acknowledgments}

The authors thank the two reviewers for their comments that have improved the quality of this paper. Dr. Mike Winter and Miss Susie Goodall are acknowledged for helpful comments. This work was supported by National Key Research and Development Program of China (Grant No 2017YFC1501005), the "Postdoctoral International Exchange Program in Lanzhou, China", the National Natural Science Foundation of China (Grant No. 41907224), the Key Technology Research and Development Program of the Ministry of Gansu Province, China (Grant No. 19ZD2FA002) and the Fundamental Research Funds for the Central Universities (Grant Nos. lzujbky-2020pd12; lzujbky-2020-sp03). 


\section{Data Availability}

744

745

The data and code that support the findings of this study are openly available in https://osf.io/b85nw/.

\section{References}

Aleotti, P., 2004. A warning system for rainfall-induced shallow failures. Engineering Geology 73 (3-4), 247-265. https://doi.org/10.1016/j.enggeo.2004.01.007

Baum, R. L., Godt, J. W., 2010. Early warning of rainfall-induced shallow landslides and debris flows in the USA. Landslides 7, 259 -272. https://doi.org/10.1007/s10346-009-0177-0.

Berti, M., Simoni, A., 2005. Experimental evidences and numerical modelling of debris flow initiated by channel runoff. Landslides 2, 171-182. https://doi.org/10.1007/s10346-005-0062-4

Berti, M., Bernard, M., Gregoretti, C., Simoni, A., 2020. Physical Interpretation of Rainfall Thresholds for Runoff-Generated Debris Flows. JGR Earth Surface 125, e2019JF005513. https://doi.org/10.1029/2019JF005513

Brunetti, M., Peruccacci, S., Rossi, M., Luciani, S., Valigi, D., Guzzetti, F., 2010. Rainfall thresholds for the possible occurrence of landslides in Italy. Natural Hazards and Earth System Sciences 10, 447-459. https://doi.org/10.5194/nhess-10-447-2010, 2010.

Buffington, J.M., Dietrich, W.E. and Kirchner, J.W., 1992. Friction angle measurements on a naturally formed gravel streambed: implications for critical boundary shear stress. Water Resources Research 28 (2), 411-425. https://doi.org/10.1029/91WR02529.

Caine, N. (1980). The rainfall intensity: duration control of shallow landslides and debris flows. Geografiska Annaler. Series A, 62, 23-27. https://doi.org/10.2307/520449.

Cannon, S. H., E. R. Bigio, and E. Mine, 2001. A process for fire-related debris flow initiation, Cerro Grande fire, New Mexico, Hydrol. Processes 15(15), 3011-3023. https://doi.org/10.1002/hyp.388

Cannon, S.H., Gartner, J.E., Wilson, R.C., Bowers, J.C., Laber, J.L., 2008. Storm rainfall conditions for floods and debris flows from recently burned areas in southwestern Colorado and southern California. Geomorphology 96, 250-269. https://doi.org/10.1016/j.geomorph.2007.03.019

Chen, G., Meng, X., Qiao, L., Zhang, Y. and Wang, S., 2018. Response of a loess landslide to rainfall: observations from a field artificial rainfall experiment in Bailong River Basin, China. Landslides 15(5), 895-911. https://doi.org/10.1007/s10346-017-0924-6 
Chen, H.X., Zhang, S., Peng, M., Zhang, L.M., 2016. A physically-based multi-hazard risk assessment platform for regional rainfall-induced slope failures and debris flows. Engineering Geology 203, 15-29. https://doi.org/10.1016/j.enggeo.2015.12.009

Chen, M.L., Liu, X.N., Wang, X.K., Zhao, T., Zhou, J.W., 2019. Contribution of Excessive Supply of Solid Material to a Runoff-Generated Debris Flow during Its Routing Along a Gully and Its Impact on the Downstream Village with Blockage Effects. Water 11, 169.

Chow, V.T., 1959. Open-channel hydraulics, New York: McGraw-Hill Book Co.

Cui, P., Hu, K., Zhuang, J., 2011. Prediction of debris-flow danger area by combining hydrological and inundation simulation methods. Journal of Mountain Sciences 8, 1-9. https://doi.org/10.1007/s11629-011-2040-8

Dijkstra, T.A., Chandler, J., et al. 2012. Geomorphic controls and debris flows - the 2010 Zhouqu disaster, China. In: Eberhardt, E., Froese, C., Turner, A. K. \& Leroueil, S. (eds) Landslides and Engineered Slopes, Proceedings of the 11th International Symposium on Landslides (ISL) and the 2nd North American Symposium on Landslides, Banff, Canada, 3-8 June, 2013. 1, CRC Press/ Balkema, Leiden, The Netherlands, 287-293.

Dijkstra, T., Wasowski, J., Winter, M., Meng, X., 2014. Introduction to geohazards of Central China. Q.J. Eng. Geol. Hydrogeol 47 (3), 195-199. https://doi.org/10.1144/qjegh2014-054

Du, J., Xie, H., Hu, Y., Xu, Y., Xu, C.Y., 2009. Development and testing of a new storm runoff routing approach based on time variant spatially distributed travel time method. Journal of Hydrology 369, 44-54. https://doi.org/10.1016/j.jhydrol.2009.02.033.

Fan, R. L., Zhang, L.M., Wang, H.J, Fan, X.M., 2018. Evolution of debris flow activities in Gaojiagou Ravine during 2008-2016 after the Wenchuan earthquake. Engineering Geology 235, $1-10$.

Fan, X. M., Juang, C. H., Wasowski, J., Huang, R. Q., Xu, Q., Scaringi, G., van Westn, C. J., Havenith, H. B., 2018. What we have learned from the 2008 Wenchuan Earthquake and its aftermath: A decade of research and challenges. Engineering Geology 241, 25-32. https://doi.org/10.1016/j.enggeo.2018.05.004

Gong, L.F., Tang, C., Xiong, J., Li, N., 2020. Debris Flow Generation Based on Critical Discharge: A Case Study of Xiongmao Catchment, Southwestern China. Water 12, 552.

Gregoretti C., 2000. The initiation of debris flow at high slopes: experimental results. Journal of Hydraulic Research 38 (2): 83-88. http://dx.doi.org/10.1080/00221680009498343

Gregoretti, C., Degetto, M., Bernard, M., Boreggio, M., 2018. The Debris Flow Occurred at Ru Secco Creek, Venetian Dolomites, on 4 August 2015: Analysis of the Phenomenon, Its 
Characteristics and Reproduction by Models. Front. Earth Sci. https://doi.org/10.3389/feart.2018.00080

Gregoretti, C., Degetto, M., Bernard, M., Crucil, G., Pimazzoni, A., De Vido, G., Berti, M., Simoni, A., Lanzoni, S., 2016. Runoff of small rocky headwater catchments: Field observations and hydrological modeling. Water Resources Research 52, 8138-8158. https://doi.org/10.1002/2016WR018675

Gregoretti, C., Fontana, G.D., 2008. The triggering of debris flow due to channel-bed failure in some alpine headwater basins of the Dolomites: Analyses of critical runoff. Hydrological Processes 22, 2248-2263. https://doi.org/10.1002/hyp.6821.

Guo, X., Cui, P., Li, Y., Zhou, Q., Kong, Y., 2016. The formation and development of debris flows in large watersheds after the 2008 Wenchuan Earthquake. Landslides 13 (1), 25-37. https://doi.org/10.1007/s10346-014-0541-6.

Guzzetti, F., Peruccacci, S., Rossi, M., Stark, C.P., 2008. The rainfall intensity-duration control of shallow landslides and debris flows: an update. Landslides 5, 3-17. https://doi.org/10.1007/s10346-007-0112-1.

Hu, W., Xu, Q., van Ash, T. W. J., Zhu, X., Xu, Q. Q., 2014. Flume tests to study the initiation of huge debris flows after the Wenchuan earthquake in S-W China. Engineering Geology 182, part B, 121-129. https://doi.org/10.1016/j.enggeo.2014.04.006

Jakob, M., \& Hungr, O., 2005. Debris-flow hazards and related phenomena. Springer, Chichester, UK, p.1.

Johnson, K.R., Ingram, B.L., Sharp, W.D., Zhang, P., 2006. East Asian summer monsoon variability during Marine Isotope Stage 5 based on speleothem $\delta{ }^{18} \mathrm{O}$ records from Wanxiang Cave, central China. Palaeogeography, Palaeoclimatology, Palaeoecology 236, 5-19. https://doi.org/10.1016/j.palaeo.2005.11.041.

Kang, Z. C., 1987. A velocity research of debris flow and its calculating method in China. Mountain Research, 5(4): 247-259 (In Chinese).

Kang, Z.C., Li, Z.F., Ma, A.N., Hu, J.T., 2004. Research on debris flow of China, Beijing: Science Publishing House (In Chinese).

Kean, J. W., McCoy, S. W., Tucker, G. E., Staley, D. M., and Coe, J. A., 2013. Runoff-generated debris flows: Observations and modeling of surge initiation, magnitude, and frequency, J. Geophys. Res. Earth Surf 118, 2190-2207. https://doi.org/10.1002/jgrf.20148.

Lamb, M.P., Dietrich, W.E., Venditti, J.G., 2008. Is the critical Shields stress for incipient sediment motion dependent on channel-bed slope? Journal of Geophysical Research 113, 
F02008. https://doi.org/10.1029/2007JF000831.

Lanzoni, S., Gregoretti, C., Stancanelli, L.M., 2017. Coarse-grained debris flow dynamics on erodible beds. JGR Earth Surface 122, 592-614. https://doi.org/10.1002/2016JF004046

Le Boursicaud, R., Pénard, L., Hauet, A., Thollet, F., Le Coz, J., 2016. Gauging extreme floods on YouTube: application of LSPIV to home movies for the post-event determination of stream discharges. Hydrological processes 30, 90-105.

Li, Y., Armitage, S.J., Stevens, T., Meng, X., 2018. Alluvial fan aggradation/incision history of the eastern Tibetan plateau margin and implications for debris flow/debris-charged flood hazard. Geomorphology 318, 203-216. https://doi.org/10.1016/j.geomorph.2018.06.016

McGuire, L.A., Rengers, F. K., Kean, J.W., Staley, D.M., 2017. Debris flow initiation by runoff in a recently burned basin: Is grain-by-grain sediment bulking or en masse failure to blame? Geophysical Research Letters 44, 7310-7319. https://doi.org/10.1002/2017GL074243

Melesse, A.M., Graham, W.D., 2004. Storm runoff prediction based on a spatially distributed travel time method utilizing remote sensing and GIS. Journal of the American Water Resources Association 40, 863-879. https://doi.org/10.1111/j.1752-1688.2004.tb01051.x

Meyer, G. A., Wells, S. G., 1997, Fire-related sedimentation events on alluvial fans, Yellowstone National Park, USA, J. Sediment. Res. 67(5), 776-791. https://doi.org/10.1306/D426863A-2B26-11D7-8648000102C1865D

Muzik, I., 1996. A GIS-derived distributed unit hydrograph. Application of Geographic Information Systems in Hydrology and Water Resources Management. Proceedings of the Vienna Conference 235, 453-460.

Parker, R., Densmore, A., Rosser, N., de Michele, M., Li, Y., Huan, R.Q., Whadcoat, S., Petley, D.N., 2011. Mass wasting triggered by the 2008 Wenchuan earthquake is greater than orogenic growth. Nature Geoscience 4 (7), 449-452. https://doi.org/10.1038/ngeo1154

Pan, H.L., Jiang, Y.J., Wang, J., Ou, G.Q., 2018. Rainfall threshold calculation for debris flow early warning in areas with scarcity of data. Nat. Hazards Earth Syst. Sci 18, 1395-1409. https://doi.org/10.5194/nhess-18-1395-2018

Papa, M., Medina, V., Ciervo, F., Bateman, A., 2013. Derivation of critical rainfall thresholds for shallow landslides as a tool for debris flow early warning systems. Hydrology and Earth System Sciences 17, 4095-4107. https://doi.org/10.5194/hess-17-4095-2013

Pastorello, R., D’Agostino, V., Hürlimann, M., 2020. Debris flow triggering characterization through a comparative analysis among different mountain catchments. CATENA 186, 104348. https://doi.org/10.1016/j.catena.2019.104348 
Railsback, L.B., Xiao, H., Liang, F., Akers, P.D., Brook, G.A., Dennis, W.M., Lanier, T.E., Tan, M., Cheng, H., Edwards, R.L., 2014. A stalagmite record of abrupt climate change and possible Westerlies-derived atmospheric precipitation during the Penultimate Glacial Maximum in northern China. Palaeogeography, Palaeoclimatology, Palaeoecology 393, 30-44. https://doi.org/10.1016/j.palaeo.2013.10.013

922

923

924

925

926

927

928

929

930

931

932

933

934

935

936

937

938

939

940

941

942

943

944

945

946

947

948

949

950

951

952

953

954

955

956

957

958

959
Reid, M.E., Coe, J.A., Brien, D.L., 2016. Forecasting inundation from debris flows that grow volumetrically during travel, with application to the Oregon Coast Range, USA. Geomorphology 273, 396-411. https://doi.org/10.1016/j.geomorph.2016.07.039

Simoni A., Bernard, M., Berti M., Boreggio M., Lanzoni S., Stancanelli L., Gregoretti C. 2020. Runoff-generated debris flows: observation of initiation conditions and erosion - deposition dynamics along the channel at Cancia (eastern Italian Alps). Earth Surface Processes and Landforms - doi:10.1002/esp.4981

Staley, D.M., Kean, J.W., Cannon, S.H., Schmidt, K.M., Laber, J.L., 2013. Objective definition of rainfall intensity-duration thresholds for the initiation of post-fire debris flows in southern California. Landslides 10, 547-562.

Staley, D.M., Negri, J.A., Kean, J.W., Laber, J.L., Tillery, A.C., Youberg, A.M.J.G., 2017. Prediction of spatially explicit rainfall intensity-duration thresholds for post-fire debris-flow generation in the western United States. Geomorphology 278, 149-162. https://doi.org/10.1016/j.geomorph.2016.10.019

Takahashi, T.J., 1978. Mechanical characteristics of debris flow. Journal of the Hydraulics Division 104 (8), 1153-1169.

Tang, C., Zhu, J., Li, W., 2009. Rainfall-triggered debris flows following the Wenchuan earthquake. Bulletin of Engineering Geology and the Environment 68 (2), 187-194. https://doi.org/10.1007/s10064-009-0201-6

Tang, C., Rengers, N., van Asch, T.W., Yang, Y., Wang, G., Luino, F., 2011. Triggering conditions and depositional characteristics of a disastrous debris flow event in Zhouqu city, Gansu Province, northwestern China. Natural Hazards \& Earth System Sciences 11, 2903-2912. https://doi.org/10.5194/nhess-11-2903-2011.

Tang, C., van Asch, T., Chang, M., 2012. Catastrophic debris flows on 13 August 2010 in the Qingping area, southwestern China: The combined effects of a strong earthquake and $\begin{array}{llll}\text { subsequent } \quad \text { rainstorms. } & \text { Geomorphology } & \text { 559-576. }\end{array}$ https://doi.org/10.1016/j.geomorph.2011.12.021.

Tang, H., McGuire, L.A., Rengers, F.K., Kean, J.W., Staley, D.M., Smith, J.B., 2019. Developing and Testing Physically Based Triggering Thresholds for Runoff-Generated Debris 
Thiene, M., Shaw, W.D., Scarpa, R., 2017. Perceived risks of mountain landslides in Italy: stated choices for subjective risk reductions. Landslides 14, 1077-1089.

Tognacca, C., Bezzola, G.R., Minor, H.E., 2000. Threshold criterion fo debris- flow initiation due to channel bed failure. In Proceedings of the Second International Conference on Debris Flow Hazards Mitigation Taipei, August, Wiezczorek, Naeser (eds), 89-97.

Wang, G., 2013. Lessons learned from protective measures associated with the 2010 Zhouqu debris flow disaster in China. Natural hazards 69, 1835-1847. https://doi.org/10.1007/s11069013-0772-1

Wang, S., Meng, X., Chen, G., Guo, P., Xiong, M., Zeng, R., 2017. Effects of vegetation on debris flow mitigation: A case study from Gansu province, China. Geomorphology 282, 64-73.

Wei, Z. L., Shang, Y. Q., Zhao, Y., Pan, P., Jiang, Y. J., 2017. Rainfall threshold for initiation of channelized debris flows in a small catchment based on in-site measurement. Engineering Geology 217, 23-34. https://doi.org/10.1016/j.enggeo.2016.12.003

Winter, M., Dixon, N., Wasowski, J., Dijkstra, T., 2010. Introduction to land-use and climate change impacts on landslides. Quarterly Journal of Engineering Geology \& Hydrogeology 43 (4), 367-370. https://doi.org/10.1016/j.geomorph.2016.12.024

Xiao, B., Wang, Q.-H., Fan, J., Han, F.-P., Dai, Q.H., 2011. Application of the SCS-CN model to runoff estimation in a small watershed with high spatial heterogeneity. Pedosphere 21, 738749. https://doi.org/10.1016/S1002-0160(11)60177-X

Xiong, M., Meng, X., Wang, S., Guo, P., Li, Y., Chen, G., Qing, F., Cui, Z., Zhao, Y., 2016. Effectiveness of debris flow mitigation strategies in mountainous regions. Progress in Physical Geography, 0309133316655304. https://doi.org/10.1177/0309133316655304

Yu, B., Wu, Y. F., Chu, S. M., 2014. Preliminary study of the effect of earthquakes on the rainfall threshold of debris flows. Engineering Geology 182, 130-135. https://doi.org/10.1016/j.enggeo.2014.04.007

Zhang, J.J., Yue, D.X., Wang, Y.Q., Du, J., Guo, J.J., Ma, J.H. and Meng, X.M., 2012. Spatial pattern analysis of geohazards and human activities in Bailong River Basin. Advanced Materials Research 518, 5822-5829. https://doi.org/10.4028/www.scientific.net/AMR.518523.5822

Zhang, Y., Meng, X., Chen, G., Qiao, L., Zeng, R. and Chang, J., 2016. Detection of geohazards in the Bailong River Basin using synthetic aperture radar interferometry. Landslides 13(5), 1273-1284. https://doi.org/10.1007/s10346-015-0660-8 

slow-moving landslides in the Zhouqu region of China using InSAR time series. Landslides 15(7), 1299-1315. https://doi.org/10.1007/s10346-018-0954-8

Zhao, Y., Meng, X., Qi, T., Qing, F., Xiong, M., Li, Y., Guo, P. and Chen, G., 2020. AI-based identification of low-frequency debris flow catchments in the Bailong River basin, China.

1012

1013

1014

1015

1016

1017

1018

1019

1020

1021

1022

1023

1024

1025

1026

1027

1028
Zhuang, J., Cui, P., Wang, G., Chen, X., Iqbal, J., Guo, X., 2015. Rainfall thresholds for the occurrence of debris flows in the Jiangjia Gully, Yunnan Province, China. Engineering Geology 195, 335-346. https://doi.org/10.1016/j.enggeo.2015.06.006

Zuazo, V., Gironás, J., Niemann, J.D., 2014. Assessing the impact of travel time formulations on the performance of spatially distributed travel time methods applied to hillslopes. Journal of Hydrology 519, 1315-1327. https://doi.org/10.1016/j.jhydrol.2014.09.035 